
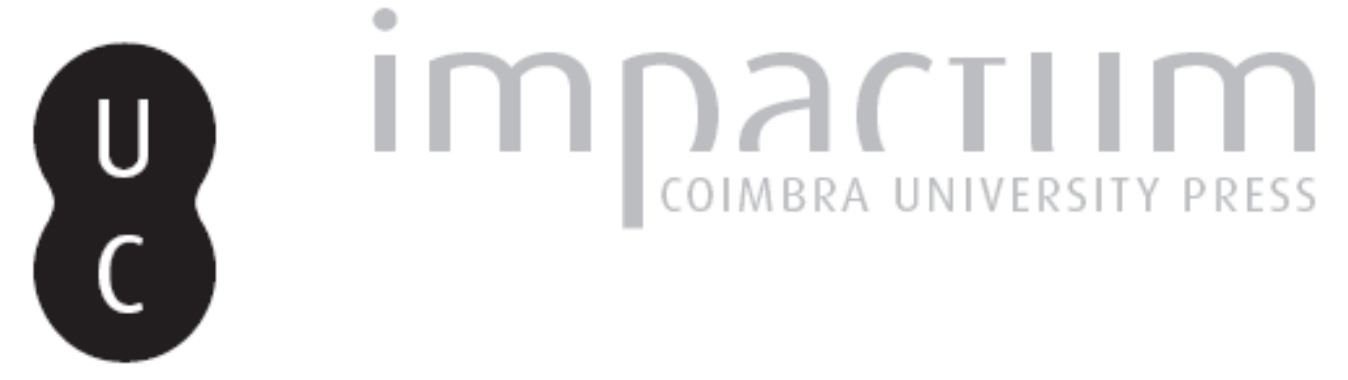

\title{
Expropriar, para o plano executar: comentário ao Acórdão do Tribunal da Relação do Porto de 7 de Maio de 2009, Processo n. $-5719 / 08-3$
}

Autor(es): $\quad$ Oliveira, Fernanda Paula

\section{Publicado por: CEDOUA}

URL persistente:

URI:http://hdl.handle.net/10316.2/40050

DOI:

DOI:https://doi.org/10.14195/2182-2387_27_6

Accessed : $\quad$ 26-Apr-2023 13:54:27

A navegação consulta e descarregamento dos títulos inseridos nas Bibliotecas Digitais UC Digitalis, UC Pombalina e UC Impactum, pressupõem a aceitação plena e sem reservas dos Termos e Condições de Uso destas Bibliotecas Digitais, disponíveis em https://digitalis.uc.pt/pt-pt/termos.

Conforme exposto nos referidos Termos e Condições de Uso, o descarregamento de títulos de acesso restrito requer uma licença válida de autorização devendo o utilizador aceder ao(s) documento(s) a partir de um endereço de IP da instituição detentora da supramencionada licença.

Ao utilizador é apenas permitido o descarregamento para uso pessoal, pelo que o emprego do(s) título(s) descarregado(s) para outro fim, designadamente comercial, carece de autorização do respetivo autor ou editor da obra.

Na medida em que todas as obras da UC Digitalis se encontram protegidas pelo Código do Direito de Autor e Direitos Conexos e demais legislação aplicável, toda a cópia, parcial ou total, deste documento, nos casos em que é legalmente admitida, deverá conter ou fazer-se acompanhar por este aviso.

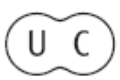



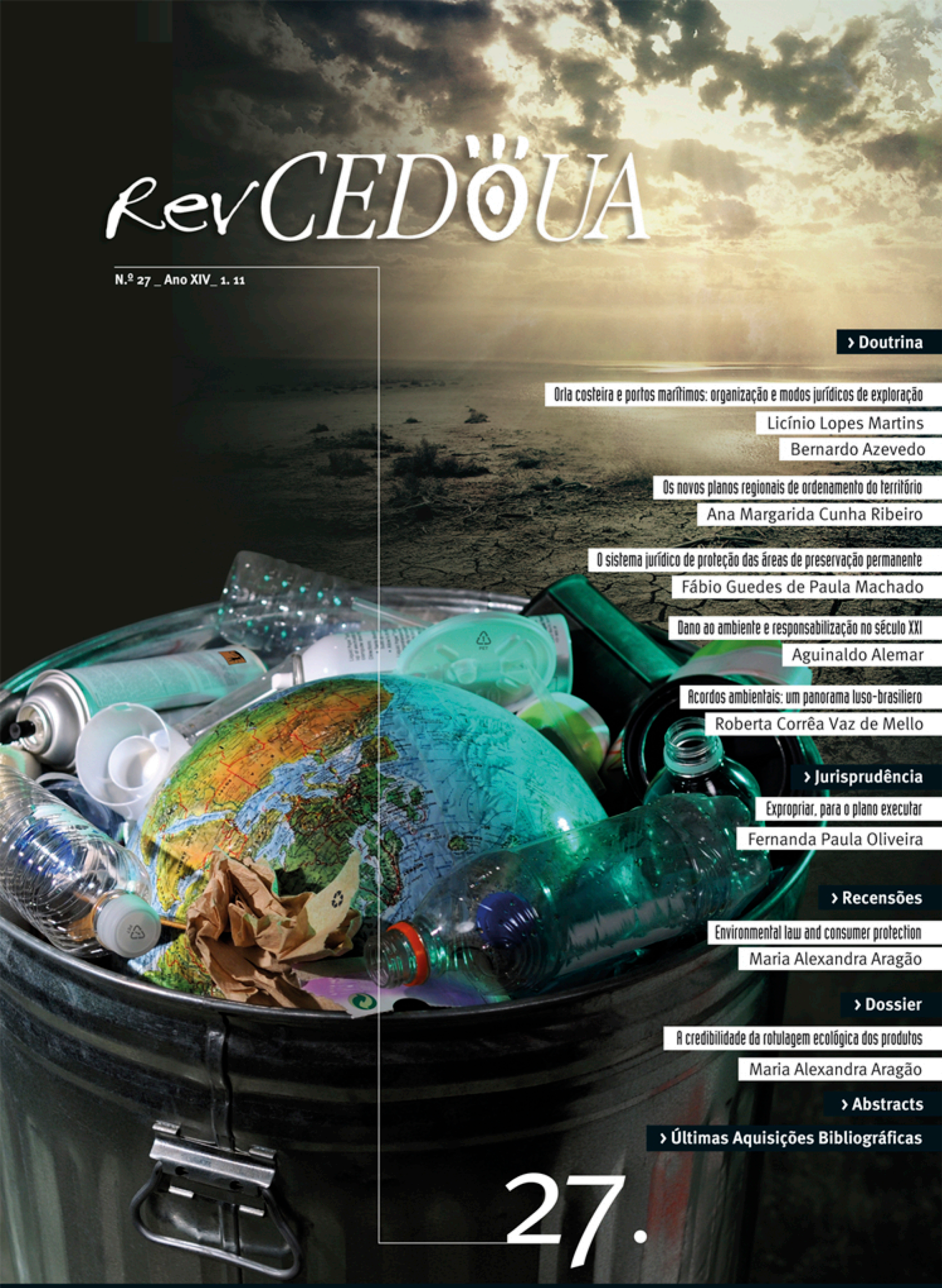

Revista do Centro de Estudos de Direito do Ordenamento, do Urbanismo e do Ambiente Urbanism, Territorial Order and Environment Studies Center Law Review 


\title{
Expropriar, para o plano executar
}

\author{
Comentário ao Acórdão do Tribunal da Relação do Porto \\ de 7 de Maio de 2009, Processo n.o $5719 / 08-3$
}

\section{(...) \\ I - RELATÓRIO:}

\section{Expropriante: Município do Porto, representado pela respectiva Câmara Municipal.}

\section{Expropriado: ......}

residente na , n. ${ }^{\circ}$......, Porto, interpôs recurso do Acórdão Arbitral proferido nos autos de expropriação da parcela n. ${ }^{\circ} 12$ do Plano de Pormenor das Antas, aprovado por deliberação da Assembleia Municipal do Porto de 29 de Abril de 2002, publicado por declaração n. ${ }^{\circ}$ 236/2002, da Direcção-Geral do Ordenamento do Território, no DR n. ${ }^{\circ} 173$ - II Série, de 29 de Junho de 2002, o qual avaliou tal parcela em $€$ 391.958,13, pretendendo ser indemnizado pelos seguintes valores: $€$ 1.270.745,00, no que concerne à moradia, $€ 317.686,25$, no que se refere ao terreno, e ainda uma quantia a encontrar pelos árbitros em relação à interrupção da actividade que o expropriado exercia na parcela, tudo com a actualização de acordo com os índices de inflação publicados pelo INE.

Partindo dos elementos constantes do auto de vistoria "ad perpetuam rei memoriam", bem como do facto de, em seu entender, o preço corrente do $\mathrm{m}^{2}$ de habitação na zona em que se insere a parcela expropriada ascender a $€ 3.500,00$, conclui pela justeza dos valores acima mencionados.

O expropriante respondeu a fls. 282 e sgs., pugnando pelo acerto da decisão arbitral. Alega que o recorrente não fundamenta suficientemente a sua pretensão, limitando-se a indicar, para cálculo da indemnização, o valor médio de venda do $\mathrm{m}^{2}$ para prédios idênticos; além disso, afirma que não se encontra minimamente demonstrado o exercício de qualquer actividade industrial por parte do recorrente no prédio expropriado, não obstante a existência de certas máquinas em determinadas divisões adstritas à fabricação de artigos de joalharia.

$\mathrm{Na}$ fase de instrução dos autos foi realizada a prova pericial, tendo os senhores peritos apresentado os seus relatórios a fls. 381 (nomeado pelo expropriante), 405 (nomeados pelo tribunal) e a fls. 418 (nomeado pelo expropriado), tendo sido indicados, respectivamente, os seguintes valores para a justa indemnização pela expropriação da parcela em causa: $€$ 455.700,00, € 503.568,00 e € 1.000.000,00.

Os senhores peritos prestaram esclarecimentos por escrito pedidos pelas partes.

Veio a realizar-se julgamento, onde foram juntos diversos documentos e pelos senhores peritos foram prestados os esclarecimentos orais, que se encontram gravados.

As partes apresentaram as suas alegações finais.

Veio a ser proferida sentença em 18.01.2008, que decidiu fixar a indemnização devida pela expropriação da parcela acima identificada em $€$ 503.568,00, a qual deve ser actualizada de acordo com a evolução do índice de preços no consumidor, com exclusão da habitação. 
Novamente inconformado, veio o expropriante apelar da sentença, tendo terminado a respectiva alegação com as seguintes CONCLUSÕES:

1. O Tribunal recorrido, não obstante ter decidido, e bem, que a justa indemnização devida ao Expropriado deve corresponder ao valor de mercado da moradia expropriada (art. $23^{\circ}, \mathrm{n} . \stackrel{0}{5}$, do Código das Expropriações), aderiu ao valor indemnizatório calculado pelos Peritos indicados pelo Tribunal, desconsiderando o Relatório de Avaliação subscrito pelo Perito Eng. ..., indicado pelo Expropriado, por entender que os valores de mercado aí ponderados se reportam a uma situação (2005/2006 - o Relatório deste Perito é de Janeiro de 2006) que não era a que se verificava à data da declaração de utilidade pública desta expropriação (2003). Segundo a Sentença, em 2006 já tinha sido parcialmente executado o Plano de Pormenor das Antas (demolição do Estádio das Antas, construção do Estádio do Dragão e demais infra-estruturas), o que determinou uma diferente valorização da zona em que se integra a moradia expropriada, por comparação à "situação que existia antes desse plano" (cfr. último parágrafo da pág. 9 da Sentença recorrida).

2. Esta decisão recorrida (i) enferma de erro nos pressupostos, pois no Relatório de Avaliação do Perito Eng. ... não foi só ponderado o mercado de 2005/2006; (ii) ignora o facto notório e atestado nos autos de que o mercado imobiliário e os valores praticados se encontram em retracção: em 2002/2003 os valores reais eram superiores aos praticados em 2005/2006; (iii) não atendeu ao facto de, à data da declaração de utilidade pública, já ter sido aprovado e publicado o Plano de Pormenor das Antas (PPA) e de as soluções urbanísticas já se encontrarem calendarizadas e em vigor, produzindo os seus efeitos e vinculando os seus destinatários.

3. - Erro nos pressupostos quanto ao mercado considerado pelo Perito Eng. ....

Ao contrário do que se pressupôs na Sentença recorrida, os valores de mercado que este Perito demonstrou e em que fundamentou a indemnização calculada, não se referem só a moradias situadas na zona de intervenção do PPA ou na zona das Antas (cfr. Anexo VII do Relatório de Avaliação deste Perito), nem só ao momento dessa avaliação, pelo que, relativamente a todas essas moradias, valores e datas anteriores, é indiferente a execução das soluções do PPA que a Sentença invoca. Na verdade, para apurar o valor de mercado de produtos idênticos a este lote de terreno com moradia construída na zona das Antas e noutras zonas do Porto, o Perito Eng. ... realizou uma pesquisa de mercado, recolhendo dados de 2003, 2004 e 2005/2006 (cfr. ponto b. do Relatório de Avaliação e o seu Anexo VII). Do mesmo modo, também quanto ao valor médio de venda da construção para habitação (apartamentos) foram consideradas outras zonas e datas. Assim, porque não se verifica a situação pressuposta na Sentença recorrida, a decisão aí proferida enferma de um manifesto erro nos pressupostos, pelo que não pode ser mantida.

4. - Os valores de mercado de 2006 são inferiores aos valores de mercado de 2002/2003.

Acresce que o mercado imobiliário (facto notório e Doc. 3 junto com as Alegações do Expropriado) se encontra numa crise reconhecida desde há já alguns anos, pelo que os valores de venda em 2005/2006, encontrados pelo referido Perito, são até inferiores aos que eram praticados em 2003. É o próprio Perito Eng. ... que afirma que esses valores reflectem um mercado em retracção (no mesmo sentido o próprio Perito da Entidade Expropriante, a fl. 383 dos autos).

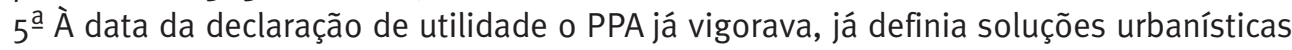
para todos os terrenos desta zona, já vinculava os seus destinatários e tinha calendarizado os termos da sua execução.

$5^{\text {a.1 }}$ Decidido, e bem, na Sentença recorrida que o critério indemnizatório a adoptar neste processo expropriativo é o do valor de mercado da moradia expropriada, a questão que aqui se coloca é a seguinte: tratando-se de uma expropriação para a execução de um 


\section{RerCEDöUA

plano pormenor, já aprovado ao tempo da declaração de utilidade pública - como é o caso dos presentes autos -, o valor de mercado a atender no cálculo da justa indemnização deve referir-se à situação que existia antes desse plano ou, pelo contrário, porque esse plano já vigorava e produzia efeitos ao tempo da declaração de utilidade esse valor e indemnização devem reflectir as soluções desse plano de pormenor?

5 ${ }^{\mathrm{a}} .20$ Expropriado defende que $\mathrm{o}$ valor de mercado a aplicar neste processo expropriativo não pode deixar de ser o que atende às soluções do Plano de Pormenor das Antas (PPA), já executadas ou com execução programada, pelo que deverá ser adoptado o Relatório de Avaliação subscrito pelo Perito Eng. ... e não os valores calculados pelos Peritos indicados pelo Tribunal. Trata-se de uma das regras mais consensuais do Direito das Expropriações que vincula o cálculo indemnizatório.

5 -3 Esta conclusão resulta, designadamente, dos seguintes factos: (a) à data publicação da declaração de utilidade pública desta expropriação o PPA já se encontrava em vigor e a produzir, de pleno, os seus efeitos; (b) ao tempo desta declaração de utilidade pública, o PPA já previa e calendarizava a execução de todas as soluções urbanísticas para zona a que se aplica. De facto, já se encontravam previstas nesse Plano (i) a demolição do Estádio das Antas, (ii) a construção do novo Estádio do Dragão, bem como (iii) construção do Hotel e (iv) da grande superfície junto a este Estádio e dos edifícios entretanto construídos (cfr. a Planta de Implantação do PPA, junta como Doc. 6 às Alegações de 24.11.2004, no recurso do Despacho do Tribunal recorrido, de 18.08.2004, bem como os arts $90^{\circ}$ e ss. do Regime Jurídico dos Instrumentos de Gestão Territorial aprovado pelo Decreto-Lei n. ${ }^{-} 380 / 99$, de 22 de Setembro).

$5^{-}$. 4 Na verdade, quando é aprovado e publicado um plano de pormenor, os cidadãos, os agentes económicos passam a saber com o que podem contar em termos urbanísticos ambientais para uma determinada zona, fundando nessas soluções urbanísticas as decisões que tomam quanto aos negócios jurídicos a celebrar relativamente a bens imóveis aí situados e quanto ao valor dos mesmos.

5 -. 5 Assim, uma conclusão: vigorando um plano urbanístico à data da declaração utilidade pública, no cálculo da indemnização e na determinação do valor de mercado deve atender-se às soluções desse plano. Nestes precisos termos, as referências jurisprudenciais doutrinais citadas nas págs. 10-15 das Alegações do Expropriado, para onde se remete este douto Tribunal, a fim de evitar desnecessárias repetições.

5 -.6 0 desacerto daquele entendimento do Tribunal recorrido é também comprovado pelo facto de antes da execução das soluções previstas no PPA e até antes da data da publicação do PPA (2002) e da data de publicação da declaração de utilidade pública que fundamentou a presente expropriação (05.02.2003), já terem sido celebrados inúmeros negócios imobiliários sobre terrenos abrangidos pelo PPA precisamente com base nas soluções urbanísticas aí previstas.

Demonstram estas conclusões os inúmeros documentos juntos aos autos, de que destacam os seguintes: (i) o Acordo entre o FCP e o Grupo Amorim de 2003, pelo qual este adquiriu àquele clube as acções das sociedades Novantas, S.A. e AzulAntas, S.A. proprietárias de diversas parcelas do PPA, por um valor superior a 16 milhões de contos, que poderia ser superior se a Câmara Municipal do Porto viesse a autorizar uma maior capacidade edificativa (cfr. Doc. 1 junto às Alegações do Expropriado - como se pode verificar no Considerando A deste Acordo, esse contrato executa um contrato-promessa de 05.04.200(?) entretanto, como se sabe, estes terrenos foram vendidos pelo Grupo Amorim ao grupo espanhol Chamartín num negócio superior a $€$ 500.000.000); (ii) e as Notícias publicadas em 2001 e 2002 em jornais da especialidade e de referência (Diário Económico), nunca desmentidas pelas entidades envolvidas (cfr. conjunto de documentos $n .{ }^{\circ} 9$ junto às Alegações do Expropriado de 24.11.2004 de recurso do despacho de adjudicação). 
$5^{\mathfrak{a} .7}$ Por outro lado, esta decisão da Sentença recorrida envolve uma gritante violação do princípio da igualdade, na sua dimensão externa, de comparação entre os expropriados e não expropriados. De facto, todos os proprietários de terrenos situados nesta zona que não foram expropriados, abrangidos pelo PPA ou não, podem beneficiar e beneficiam (através negócios jurídicos ou da sua efectiva vivência na zona) das soluções urbanísticas aí previstas, só os expropriados, para além de coercivamente contribuírem para esse fim e de verem o seu direito de propriedade extinto por fins de utilidade pública, não poderão beneficiar dessas soluções urbanísticas, nem mesmo para efeitos de fixação da justa indenmização devida para essa expropriação. Esta leitura do Direito e da Justiça não pode ser aceite.

5 a .8 Acresce que o Expropriado foi excluído do reparcelamento e do sistema de perequação compensatória estabelecido no PPA (cfr. Doc. 2 junto às Alegações do Expropriado), pelo que se também aqui, em sede de indemnização devida por essa expropriação, o Expropriado não puder ver reflectidas as soluções urbanísticas desse Plano assistir-se-á a uma nova violação do princípio da igualdade e da justiça.

5‥ 9 Do mesmo modo, importa salientar que da declaração de utilidade pública desta expropriação não resultam quaisquer mais-valias. De facto, as soluções urbanísticas cuja consideração está aqui em causa são as soluções estabelecidas no Plano de Pormenor das Antas que já vigorava ao tempo desta declaração de utilidade pública e de que beneficiam todos os proprietários desta zona. Desta declaração de utilidade pública só resulta a necessária demolição da vivenda do expropriado e a construção de edifícios de 5/6 pisos destinados habitação e serviços: é este o incrivel fim desta expropriação.

6 $\underline{a}$ Do mesmo modo, ao contrário do que a Sentença pressupôs, alguns dos edifícios que foram construídos na zona do PPA não são de luxo (assim, por exemplo, o conjunto Studio Residence, vocacionado para estudantes) e a moradia do Expropriado tinham efectivamente acabamentos de luxo como foi reconhecido na vistoria ad perpetuam rei memoriam e na própria Sentença recorrida (cfr. Doc. 4 junto com as Alegações do Expropriado).

$7^{\underline{a}}$ Assim, porque o Perito Eng. ... foi o único a ponderar as soluções urbanísticas que resultam do PPA e os valores efectivamente praticados no mercado, deve ser ao valor aí calculado que este douto Tribunal deve aderir na fixação da justa indemnização devida ao Expropriado e que se traduz numa indemnização global de $€ 1.000 .000$, a que corresponde um valor unitário de $€ 2.750 / \mathrm{m} 2$ de construção (valor este inferior ao valor de venda de todas as moradias com características idênticas a moradia expropriada e, inclusive ao de diversos apartamentos também com boa qualidade de construção e acabamentos da cidade do Porto - cfr. Anexo VIII ao Relatório deste Perito, a fls. 503-505).

$8^{\text {a }}$ Não obsta a esta adesão o facto de, como se critica na Sentença recorrida, aquele Perito ter calculado uma indemnização, de acordo com os critérios referenciais estabelecidos, nos arts. $26^{\circ}$ e ss. do Código das Expropriações, superior ao valor de mercado do bem expropriado, pois, se é certo que normalmente nos deparamos com situações em que o valor de mercado do bem expropriado é superior ao que resulta daqueles critérios, não é menos verdade que noutras situações se verifica efectivamente o inverso: é o que acontece, por exemplo, nas situações previstas no art. $26^{\circ}$, n. $^{\circ}$ 12, do Código das Expropriações: nessas situações, em que valor de mercado do terreno é muito reduzido (assim, por exemplo, se estiver classificado como zona verde ou de lazer), o expropriado irá receber uma indemnização calculada nos termos aí referidos (atendendo à edificabilidade média dos terrenos envolventes - isto é, uma edificabilidade que o terreno expropriado efectivamente não tem) e que determina um valor superior ao valor de mercado do bem; é o que acontece, também, nas expropriações dos imóveis situados em zonas social e urbanisticamente muito degradadas, onde os terrenos, classificados como aptos para a construção e indemnizados de acordo com os critérios dos arts. $26^{\circ}$ e ss. do Código das 
Expropriações podem conduzir a valores superiores respectivos valores de mercado (muito desvalorizados, por aqueles mesmos factores de degradação).

$9^{\underline{a}}$ Deste modo, a conclusão de que a justa indemnização a atribuir ao Expropriado por esta expropriação não pode deixar de reflectir, no valor de mercado aí ponderado, as soluções urbanísticas que resultam do PPA, já aprovado, em vigor e a produzir os seus efeitos à data da declaração de utilidade pública expropriativa.

A interpretação do art. $23^{\circ}$, n. ${ }^{-} 1$, do Código das Expropriações, no sentido de que a justa indemnização não deve considerar as soluções previstas num plano de pormenor em vigor data da declaração de utilidade pública, onde se definem as soluções urbanísticas dos solos abrangidos e se calendariza a respectiva execução, é inconstitucional, por violação princípio da igualdade dos cidadãos perante os encargos públicos, do direito fundamental dos Expropriados a uma justa indemnização e do Estado de Direito (arts. $2^{\circ}, 13^{\circ}$ e $62^{\circ}$ da Constituição).

10 a Para além da indemnização devida pela expropriação da moradia, cumpre ainda indemnizar os prejuízos resultantes do período de paralisação e reinstalação da actividade industrial exercida na parcela expropriada (artigo $31^{\circ}$, n. ${ }^{\circ}$, do Código das Expropriações pois, ao contrário do que se referiu na Sentença recorrida, resulta efectivamente demonstrado nos autos a existência de um estabelecimento industrial de ourivesaria. Falamos designadamente, da vistoria ad perpetuam rei memoriam - cfr. fl. 24 dos autos, bem como respectivos Anexos II e III, a fls. 96-97 do processo da Câmara Municipal apenso aos autos mas também do próprio facto 28 da Sentença recorrida, pag. 5 .

Também quanto a esta dimensão indemnizatória, deverá este douto Tribunal adoptar a avaliação efectuada pelo Perito Eng. ..., tanto mais que nenhuma das outras avaliações constantes dos autos o fez. Assim, um valor indemnizatório de $€ 20.000$ (no sentido de ser devida esta indemnização, o Acórdão deste douto Tribunal de 19.01.1993, Processo 9210518, www.dgsi.pt, citado na pág. 22 das Alegações do Expropriado).

11 - Por último, deverão ainda ser indemnizados os custos que o Expropriado teve com a mudança da sua residência para um outro local e que se estimam, pelo menos, em $€ 6.500$ (cfr. Documento junto aos Esclarecimentos prestados pelo Eng. ..., a fl. 57_ dos autos), bem como o valor do IMT que o Expropriado terá que suportar na aquisição de uma nova moradia deste valor ( $6 \%$ do valor da aquisição - cfr. art. $17^{\circ}, n^{\circ}$ s. 1 e 2, do CIMT).

Houve contra Alegações de recurso da expropriante, concluindo pela manutenção julgado. Nas contra Alegações a apelada levanta como questão prévia a inadmissibilidade junção de documentos pelo apelante nas Alegações de recurso.

Colhidos os vistos legais, cumpre decidir.

\section{II- DO RECURSO:}

\section{Questão prévia:}

Como é pacífico na doutrina e jurisprudência nacionais "a lei reguladora da expropriação é a vigente à data da publicação da declaração de utilidade pública"1.

No caso "sub judice", a declaração da utilidade pública da expropriação resultou da deliberação da Assembleia Municipal do Porto de 27.12.2002, publicada no Diário da República, II Série, apêndice n.ํ21, de 5 de Fevereiro de 2002.

${ }^{1}$ Cfr., a propósito, José Osvaldo Gomes, in Expropriações por Utilidade Pública, pág. 328; Prof. Meneses Cordeiro, in CJ, Ano XI, Tomo V, 24; Ac. TJ de 20.11.1980, 301, pág.309; Ac. RL de 10.03.1994, CJ 1994, T. II, pág. 83; Ac. RL de 23.03.1995, CJ, 1995, T. Il, pág. 89, Ac. RL de 25.05.202, CJ 202, t. III, p.75 


\section{$\operatorname{RerCEDöUA~}$}

> Jurisprudência

Por conseguinte, a lei aplicável "in casu" é o Código das Expropriações aprovado pela Lei n. ${ }^{168 / 99}$, de 18.09, entrado em vigor em 18.11.1999, conforme prescreve o artigo $4^{\circ}$ da referida Lei (diploma a que pertencerão todas as posteriores referências legislativas, salvo menção em contrário)".

Acresce que, o processo judicial de expropriação litigiosa é um processo especial, que corre nos tribunais comuns, sendo regulamentado especificamente pelo C.E.

Em tudo o que não estiver previsto nas disposições próprias do C.E. segue o regime do processo ordinário estabelecido no C.P.C.

Ora, da sentença proferida pelo tribunal de comarca foi interposto recurso pelo expropriado ao abrigo do disposto no art $^{\circ} 66^{\circ}, \mathrm{n} . .^{\circ}$ 2, Código das Expropriações e que foi admitido como de apelação sendo-lhe aplicável as disposições próprias deste recurso ordinário art $^{\circ} 691$ ss e as gerais dos arto $676^{\circ}$ ss CPC.

Isto posto, será à luz das normas do referido Código das Expropriações e do Código de Processo Civil vigentes (lei temporalmente aplicável) que a questão prévia levantada pela apelada e as questões colocadas pelo apelante em recurso se hão-de decidir.

0 Código das Expropriações prevê nos seus artigos $58^{\circ}$ e $60 . .0$ dever processual do recorrente e recorrido apresentarem com o requerimento de interposição de recurso ou a resposta ao recurso da decisão arbitral "todos os documentos" que julguem necessários para a fixação da justa indemnização, que é o objecto do processo de expropriação na sua fase judicial, conforme prescreve $0 \operatorname{art}^{\circ} 66^{\circ}, n .{ }^{\circ} 1$, Cód. Expropriações.

Acresce que, conforme hoje resulta claramente do disposto nos $\operatorname{art}^{\circ} \mathrm{S} 23^{\circ}, \mathrm{n} . ._{1}-2^{\circ}$, n. .1 , CE, o montante da justa indemnização será calculado com referência à data da DUP, valor esse actualizado à data da decisão final do processo de acordo com a evolução do índice de preços no consumidor com exclusão da habitação.

Daqui decorre que, pela aplicação da referida norma própria deste processo especial de expropriação por utilidade pública urgente, a junção dos documentos com as alegações de recurso do apelante é processualmente inadmissível.

Esta tem sido a jurisprudência dominante nos tribunais superiores - vide Ac RL de 12.03.1998, CJ ano XXIII, T II, p. 93, Ac RC de 5 de Julho de 2005, CJ ano 2005, T. IV, p. 5 e AC STJ de 20.01.2005, www.dgsi.pt.

Mesmo que se admitisse a junção de documentos na fase de recurso da sentença, ao abrigo do disposto no art $^{\circ} 706^{\circ} \mathrm{CPC}$, tal apenas poderia ser admissível se:

- a junção dos documentos não fosse possível até ao encerramento da discussão de julgamento;

- a junção se ter tornado necessária em virtude do julgamento proferido na primeira instância;

- o documento seja superveniente por se destinar a prova de factos posteriores ao encerramento da discussão.

Ora, o apelante junta com as alegações de recurso cinco documentos.

Os documentos 4 e 5 são excertos de documentos que já constam dos autos, respectivamente Vistoria ad perpetuam rei memoriam e Relatório do Plano de Pormenor das Antas, pelo que a junção dos referidos excertos parcelares e absolutamente desnecessária e impertinente.

Quanto aos documentos 1 a 3, trata-se o primeiro de cópia de um acordo celebrado em 19.05.2003 entre o Futebol Clube do Porto, a Aplicação Urbana II - Investimento Imobiliário, SA e a Amorim SGPS, SA, o segundo da Planta de Pormenor das Antas referente à operação de reparcelamento e o terceiro constitui um conjunto de notícias publicadas na imprensa em 2007 e um relatório da Federação Portuguesa da Indústria da Construção e Obras Públicas de 2006.

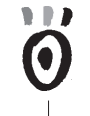


Ora, tais documentos são também desnecessários e impertinentes aos presentes autos.

Com efeito, o primeiro documento diz respeito a, um acordo de venda do Futebol Clube do Porto, a Aplicação Urbana II- Investimento Imobiliário, SA da totalidade das acções representativas do capital social das sociedades comerciais Novantas SA e Azulantas, SA, pelo preço de $€$ 84.711.959,18, que nenhum interesse tem para a fixação da indemnização devida pela expropriação da parcela dos autos reportada à data da DUP e despida de factores especulativos, nem sequer para efeitos de eventual comparação dos valores de mercado.

O segundo, no que de interesse para os ditos fins deste processo diz respeito já a respectiva Planta de Pormenor foi considerada nos presentes autos, quer aquando da Vistoria ad perpetuam rei memoriam, quer aquando dos relatórios periciais.

0 conjunto do terceiro documento diz respeito a notícias de imprensa e a um relatório meramente opinativo de uma entidade associativa dos industriais da construção civil sobre a situação dessa indústria e também nenhum interesse tem para os ditos fins deste processo.

Por tudo o exposto, não sendo nesta fase de determinar o desentranhamento desses documentos, certo é que os mesmos não podem ser considerados nesta fase de recurso de apelação.

\section{Questões em recurso:}

Quanto ao recurso de apelação do expropriado, deve ter-se em conta que:

0 objecto do recurso é delimitado pelas conclusões da alegação da recorrente, não podendo este Tribunal conhecer de matérias nelas não incluídas, sem prejuízo das de conhecimento oficioso - $\operatorname{art}^{\circ} \mathrm{s} 684^{\circ}, \mathrm{n} .^{\circ} 3$ e $690^{\circ}, \mathrm{n} .^{\circ} \mathrm{s} 1$ e 3, do Código de Processo Civil;

Nos recursos apreciam-se questões e não razões;

0 recurso está limitado pela questão e decisão recolhida;

Apreciemos então as questões apresentadas nas Alegações do expropriado-apelante:

- A justa indemnização a atribuir ao Expropriado por esta expropriação não pode deixar de reflectir, no valor de mercado aí ponderado, as soluções urbanísticas que resultam do PPA, já aprovado, em vigor e a produzir os seus efeitos à data da declaração de utilidade pública expropriativa.

- A interpretação do art. $23^{\circ}, n . \underline{o}_{1}$, do Código das Expropriações, no sentido de que a justa indemnização não deve considerar as soluções previstas num plano de pormenor em vigor à data da declaração de utilidade pública, onde se definem as soluções urbanísticas do solos abrangidos e se calendariza a respectiva execução, é inconstitucional, por violação do princípio da igualdade dos cidadãos perante os encargos públicos, do direito fundamental dos Expropriados a uma justa indemnização e do Estado de Direito (arts. $2^{\circ}, 13^{\circ}$ e $62^{\circ}$ da Constituição).

- deve, assim, ser considerado como indemnização pelo valor da moradia e respectivo terreno de logradouro do expropriado, que constitui a parcela expropriada, o valor global de $€ 1.0000,00$, a que corresponde o valor unitário de 62.750,00/m2, atribuído no laudo do perito indicado pelo expropriado.

- Para além da indemnização devida pela expropriação da moradia, cumpre ainda indemnizar os prejuízos resultantes do perío do de paralisação e reinstalação da actividade industrial exercida na parcela expropriada (artigo $31^{\circ}, n .{ }_{1}$, do Código das Expropriações), pois, ao contrário do que se referiu na Sentença recorrida, resulta efectivamente demonstrado nos autos a existência de um estabelecimento industrial de ourivesaria. Falamos, designadamente, da Vistoria ad perpetuam rei memoriam - cfr. fl. 24 dos autos, bem como respectivos Anexos II e III, a fls. 96-97 do processo da Câmara Municipal apenso aos autos - mas também do próprio facto 28 da Sentença recorrida, pág. 5.

-Também quanto a esta dimensão indemnizatória, deverá este douto Tribunal adoptar a avaliação efectuada pelo Perito Eng. ..., tanto mais que nenhuma das outras avaliações 
constantes dos autos o fez. Assim, um valor indemnizatório de $€ 20.000$ (no sentido de ser devida esta indemnização, o Acórdão deste douto Tribunal de 19.01.1993, Processo n.. 9210518, www.dgsi.pt, citado na pág. 22 das Alegações do Expropriado).

-Por último, deverão ainda ser indemnizados os custos que o Expropriado terá com a mudança da sua residência para um outro local e que se estimam, pelo menos, em € 6.500 (cfr. Documento junto aos esclarecimentos prestados pelo Eng. ..., a fl. 570 dos autos), bem como o valor do IMT que o Expropriado terá que suportar na aquisição de uma nova moradia deste valor ( $6 \%$ do valor da aquisição - cfr. art. $17^{\circ},{ }^{\circ} .{ }^{\circ}$ S. 1 e 2, do CIMT).

NA SENTENÇA RECORRIDA FIXARAM-SE OS SEGUINTES FACTOS PROVADOS com relevo para a decisão, que emergem, designadamente, do auto de vistoria ad perpetuam rei memoriam, do acórdão arbitral, dos laudos dos peritos e dos documentos juntos aos autos:

1) Por deliberação da Assembleia Municipal do Porto de 29 de Abril de 2002, foi aprovado o Plano de Pormenor das Antas, publicado por declaração n. ${ }^{\circ} 236 / 2002$, da Direcção Geral do Ordenamento do Território e Desenvolvimento Urbano, no DR n. ${ }^{\circ} 173$-II Série, de 29 de Julho de 2002.

2) A parcela de terreno designada no processo por, parcela 12, com a área de $370 \mathrm{~m} 2$, do prédio sito na $A v .^{\text {a }}$..., n..$^{\circ}$...., na freguesia de Campanhã, da cidade do Porto, está integrada na área delimitada pela planta de implantação do aludido Plano de Pormenor, designadamente pela sua confrontação poente, que corresponde à Av. a Fernão de Magalhães.

3) A parcela referida no ponto anterior corresponde a uma casa de habitação, anexos e logradouro, inscrita na matriz predial urbana sob o art. ${ }^{\circ}$...., descrita na CRP do Porto sob o n. ${ }^{\circ} . . . / 19971218$, encontrando-se aí inscrita a aquisição do respectivo direito de propriedade a favor de

4) Em reunião de 12 de Novembro de 2002, a Câmara Municipal do Porto tomou, nos termos do art. ${ }^{\circ}$ 10. do Código das Expropriações, a resolução de requerer a declaração de utilidade pública com carácter de urgência da referida parcela, tendo notificado o proprietário por carta registada do dia 26 de Novembro de 2002.

5) Em reunião de 17 de Dezembro de 2002, foi a aludida resolução ratificada, tendo sido notificado o proprietário por carta registada de 19 de Dezembro de 2002.

6) Por deliberação da Assembleia Municipal do Porto de 27 de Dezembro de 2002, publicada no Diário da República, II Série, apêndice n. ${ }^{\circ} 21, n .^{\circ} 30$, de 5 de Fevereiro de 2003, foi declarada a utilidade pública com carácter de urgência do prédio urbano sito na Av..$^{\text {a }}$ Ferrão de Magalhães, n. ${ }^{\circ}$...., freguesia de Campanhã, da cidade do Porto.

7) A parcela em causa tem a área total de $370 \mathrm{~m}^{2}$.

8) No terreno da parcela está implantado um edifício de cave, rés-do-chão e andar, com a superfície coberta de 8,72m x 11,70m, o que perfaz $102 \mathrm{~m}^{2}$, e a área de $3 \times 102,024$, 0 que perfaz 306,07 $\mathrm{m}^{2}$.

9) Nas traseiras do edifício, encostados à estrema nascente da parcela, estão construídos dois anexos destinados a garagem, com a superfície coberta de $25 \mathrm{~m}^{2}$ e a arrecadação, com 32 m2 de superfície coberta.

10) 0 terreno da parcela tem configuração geométrica rectangular, marginado a poente pela Av. a Fernão de Magalhães, para a qual possui uma frente de 11,50 metros e uma profundidade média de 32,0 metros.

11) O solo da parcela é de topografia plana e está de nível com o arruamento que a faceia a poente.

12) Com um afastamento de 5,0 metros da estrema do lado poente e de 3,0 metros da estrema do lado norte da parcela, está construída no solo da mesma uma moradia de três frentes, composta de cave, rés-do-chão e andar, sendo o rés-do-chão e o andar destinado a habitação do proprietário. 


\section{$\operatorname{RerCED\varrho ̋UA~}$

13) Trata-se de uma construção com cerca de 20 anos.

14) A fachada principal da zona do rés-do-chão é revestida com placas de granito rosa, as varandas são dotadas de gradeamento artístico de ferro pintado, sendo os tectos dos alpendres adjacentes às varandas da fachada principal e de parte da fachada norte revestidos a madeira exótica trabalhada manualmente.

15) Os pisos são separados por placas de betão armado e a cobertura é feita por placa de betão armado revestida a telha preta.

16) O pavimento do hall de entrada do rés-do-chão é revestido com um desenho atapetado em granito de cor rosa com orla de pedra preta.

17) Os restantes pavimentos deste piso são constituídos por réguas de madeira maciça de sucupira com $3 \mathrm{~cm}$ de espessura.

18) Os pavimentos do $10^{\circ}$ andar são, em réguas de madeira flutuante.

19) Os pavimentos da cave são em tijoleira.

20) Os tectos do rés-do-chão e do primeiro andar são em gesso com moldura.

21) Todas as portas (portadas e janelas) são de madeira de sucupira, trabalhadas manualmente e dotadas de fecho de boca de lobo, todas envidraçadas com vidro lapidado e foscas, sendo protegidas com portas de segurança em ferro trabalhado.

22) Exteriormente, todas as portadas são dotadas com persianas em PVC.

23) Na fachada norte está inserida a chaminé do fogão de sala do rés-do-chão, revestida de azulejo decorativo.

24) Na frente do edifício, constituindo o acesso principal a moradia, existe uma escadaria curvilínea em pedra polida preta de granito com cinco degraus e um patamar com cerca de $3 \mathrm{~m}^{2}$, encimada por alpendre revestido a madeira exótica trabalhada manualmente com $4 \mathrm{~m}^{2}$ de superfície.

25) A zona de rés-do-chão é constituída por hall de entrada, sala de visitas, sala de jantar, cozinha e casa de banho completa com antecamara. Dispõe de cinco portadas interiores de madeira exótica maciça, manufacturadas, com caixilharias em vidro biselado. Além disso, tem dois fogões de sala, um em mármore polido e outro em granito, ambos com recuperador de calor. 0 pavimento da cozinha é constituído por placas de granito de cor rosa, ornamentadas com faixa de madeira de sucupira. 0 tecto da cozinha é constituído por réguas de madeira de sucupira, com orla de "coroa de rei".

26) 0 primeiro andar e constituído por quatro quartos e duas casas de banho completas.

27) A escadaria de acesso ao primeiro andar é de madeira, com corrimão assente em balaustres, tudo em madeira exótica maciça.

28) A cave é composta por uma sala de bilhar, casa de banho e três divisões que contém maquinaria destinada a actividade de ourivesaria.

29) A parte traseira da cave, onde se localiza a sala de bilhar, situa-se ao nível do solo do terreno do quintal.

30) Todas as divisões da cave dispõem de luz natural, sendo a sua zona poente dotada de janelas térreas.

31) Todo o edifício da moradia dispõe de sistema de alarme.

32) Na zona nascente da parcela, encostados a estrema do prédio, estão implantados dois anexos:

a) garagem, com a superfície coberta de $5 \times 5$ metros, construída em paredes de alvenaria de tijolo, rebocadas e pintadas, com cobertura de placa de cimento armado impermeabilizada com telas isolantes, dotada de porta de madeira maciça trabalhada e envernizada;

b) arrecadação, com a superfície coberta de $8 \times 4$ metros, com carcaterísticas de construção idênticas às da garagem, dotada de uma porta de madeira e de uma janela com estrutura de ferro, sendo os caixilhos envidraçados. 
33) A parcela contém ainda o seguinte:

a) pavimentos decorativos, revestindo parcialmente a superfície descoberta da parcela numa área de $170 \mathrm{~m}^{2}$, constituído por placa de basalto e calcário;

b) muro de vedação, no limite poente, rebocado e pintado, com 1,20 metros de altura e 0,40 metros de espessura, encimado por grade de ferro trabalhada e revestida com chada de ferro pintada, tendo rasgadas duas entradas, uma para pessoas, outra para viaturas, ambas dotadas de portões constituídos com estrutura de ferro chapeados e pintados, dotados de comando eléctrico de abertura. 0 muro é encimado por cinco esferas de granito maciço, tipo bola de basquetebol, com 0,35 metros de diâmetro;

c) muro de vedação da estrema norte construído em alvenaria de pedra, rebocado e pintado, com 1,5 metros de altura e encimada por placas de ferro pintadas;

d) sebe de escalóneas, bastante densa, ao longo do muro referido em c), com sistema de rega automático.

34) $A$ Av. - Fernão de Magalhães, acima referida, tem, no local da parcela, 25 metros de largura, sendo um importante eixo viário da zona nordeste da cidade do Porto, com pavimento betuminoso, dispondo de passeios, redes de abastecimento domiciliário de água, saneamento, drenagem de águas pluviais, estação depuradora, em ligação com a rede colectora de saneamento com serviço junto da parcela, rede distribuidora de gás e rede telefónica.

35) A referida avenida, na zona da parcela, era tradicionalmente ladeado por casas de habitação isoladas de 2 e 3 pisos, construções de grande qualidade, com jardim na frente e nas traseiras dos edifícios.

36) Na área envolvente da parcela, a menos de 100 metros de distância da mesma, localizam-se a Igreja das Antas, a torre de escritórios das Antas, com 16 pisos acima do solo, o "antigo" Estádio das Antas e o actual Estádio do Dragão e respectivo complexo desportivo e comercial, a loja restaurante McDonald's e diversos edifícios de habitação colectiva. A cerca de 200 metros, encontra-se a Praça Francisco Sá Carneiro (antiga Praça Velasquez), que constitui um espaço público agregador, núcleo social, de comércio e serviços.

37) No Plano de Pormenor da Antas, a parcela $n .^{\circ} 12$ localiza-se em área classificada como Zona Mista de Densidade 2.

38) As Zonas Mistas são predominantemente destinadas ao uso de habitação, comércio, serviços e equipamentos complementares.

\section{Ainda resultam provados documentalmente os seguintes factos como interesse para a decisão da causa:}

39) Em 25.02.2005 foi proferido despacho transitado em julgado, que ordenou a entrega ao expropriado de precatório cheque no valor de $€ 391,502,13$ retirado do montante indemnizatório depositado nos autos pela entidade expropriante após a decisão arbitral.

40) Pelo despacho de 05.03.2008, transitado em julgado, foi ordenado o depósito pela expropriante do montante de $€ 154,088,24$, relativo a actualização da indemnização fixada na Sentença recorrida, montante que foi entregue ao expropriado em 02.06.2008 (fls. 997).

41) A entidade expropriante tomou posse administrativa da parcela expropriada em 28/05/01 (fls. 40 e 41).

42) Teve lugar a vistoria " ad perpetuam rei memoriam " da parcela expropriada em 22.01.2004 (fls. 21 a 26 do I Volume).

43) Procedeu-se a arbitragem nos termos legais, tendo os árbitros nomeados decidido, por unanimidade, atribuir a título de indemnização ao proprietário da parcela expropriada a quantia de $€ 391.958,13$ (fls. 29 a 32).

44) A fls. 38 dos autos está comprovado o depósito dessa quantia fixada na decisão arbitral.

45) 0 interessado ... é titular inscrito no registo predial do referido imóvel, pela apresentação 11 de 18-1- 1997. 


\section{RerCED光UA

São apenas estes os factos que esta Relação entende como provados e com interesse para a decisão de direito, sendo certo que o expropriado não interpôs recurso da fixação da matéria de facto expressa na Sentença, de acordo com o que impõem os artigos $690^{\circ}$-A, CPC, nem se verificam fundamentos para alterar a matéria de facto referida na Sentença ou ordenar a sua ampliação de acordo com o disposto no art. ${ }^{\circ} 712^{\circ} \mathrm{CPC}$.

Isto posto, há que dizer que, como se entendeu na Sentença, é o Código das Expropriações de 1999, aprovado pela Lei n. $-168 / 99$, de 18.09 - doravante designado apenas por Código das Expropriações - o aplicável à presente expropriação, por a declaração de utilidade pública ter sido emitida na sua vigência - neste sentido, Fernando Alves Correia, As Grandes Linhas da Reforma do Direito Urbanístico Português, Coimbra, 1993, p.70, Ac. RL, 10.03.1994, CJ, Ano XIX, T. II, p. 83, Ac. RL, 21.05.2002, CJ, t. III, p 75 e Ac RP, 13.02.1997, T.I, p.228.

Assim, por força do disposto no art. $.24^{\circ}$, n. .1 , C. Exp.,"O montante da indemnização calcula-se com referência à data da declaração de utilidade sendo actualizado à data da decisão final do processo de acordo com a evolução do índice de preços no consumidor, com exclusão da habitação".

Como se sabe, «a expropriação é o acto administrativo pelo qual a Administração Pública decide, com base na lei, extinguir um direito subjectivo sobre um bem imóvel privado, com fundamento na necessidade dele para a realização de um fim de interesse público e, consequentemente, se apropria desse bem, ficando constituída na obrigação de pagar ao titular do direito sacrificado uma justa indemnização» (Freitas do Amaral, Direito do Urbanismo (Sumários), Lisboa, 1993, p. 90).

Na verdade, 0 art. $23^{\circ}, n^{\circ}{ }^{\circ} 1$ e 2 , 1. ${ }^{a}$ parte, Cód. Expropriações, estabelece, por imperativo constitucional (cf. art. $62 .^{\circ}, \mathrm{n} .^{\circ} 2$, da CRP) e numa orientação que remonta à Lei n. ${ }^{\circ}$ 2030, de 22 de Janeiro de 1948 e ao Regulamento das Expropriações aprovado pelo Decreto n. ${ }^{\circ} 43587$, de 8 de Abril de 1961, que a expropriação por utilidade pública de quaisquer bens ou direitos confere ao expropriado o direito de receber o pagamento contemporâneo de uma justa indemnização, a qual não visa compensar o benefício alcançado pelo expropriante, mas ressarcir o prejuízo que para o expropriado advém da expropriação (cf. Ac. RP de 6.06.91, CJ, XVI, t. 3, p. 252, e Ac. RE de 30.01.92, CJ, XVII, t. 1, p. 269). 0 princípio da indemnização, diz Alves Correia (Garantias do Particular na Expropriação por Utilidade Pública, Separata do volume XXIII do suplemento do BFDUC, Coimbra, 1982, p. 120 e ss.), é um pressuposto de legitimidade do acto expropriativo e, logo, um elemento integrante do próprio acto de expropriação (Gomes Canotilho / Vital Moreira, Constituído da República Portuguesa Anotada, II, 2. a ed., Coimbra, 1984, p. 337).

Como se diz no Ac. do Tribunal Constitucional n. ${ }^{\circ} 140 / 03$, da 1. ${ }^{\text {a }}$ Secção, proferido no processo n. $.593 / 02^{2}$, «aquele preceito constitucional determina que a indemnização por expropriação deve ser justa, mas não define qualquer critério indemnizatório de aplicação directa e objectiva, nem contém qualquer indicação sobre o método ou mecanismo de avaliação do prejuízo derivado da expropriação. É este um problema de técnica legislativa, cuja escolha foi deixada pela Constituição ao legislador ordinário».

«Apesar disso, a expressão "justa indemnização", inserta no artigo 62.\% 2, da Lei Fundamental, não pode ser considerada como uma fórmula vazia. É, antes, uma fórmula carregada de sentido, na qual podem ser colhidos importantes limites à discricionariedade do legislador ordinário». 


\section{RerCEDöUA}

> Jurisprudência

Alves Correia (O Plano Urbanístico e o Princípio da Igualdade, Coimbra, 1989, ps. 532 e ss.) defende que o conceito constitucional de «justa indemnização» pressupõe: (i)) a proibição de uma indemnização meramente nominal, irrisória ou simbólica; (ii)) o respeito pelo princípio da igualdade de encargos; e (iii)) a consideração do interesse público da expropriação.

Atendo-nos apenas à primeira e à segunda dimensões - aquelas que têm a ver com o princípio da justiça da indemnização visto na direcção do expropriado - , refere que no conceito de justa indemnização vai implícito o sentido de que devem ser rejeitados por inconstitucionais os critérios conducentes a uma indemnização meramente nominal (blösse Nominalentschädigung), a uma indemnização puramente irrisória ou simbólica ou a uma indemnização simplesmente aparente. Estar-se-á perante uma indemnização meramente simbólica quando, por exemplo, a lei, baseando-se num critério abstracto, que não faça qualquer referência ao bem a expropriar e ao seu valor segundo o seu destino económico, permite indemnizações que não se traduzem numa compensação adequada do dano infligido ao expropriado.

Além disso, no conceito de justa indemnização vai implicada necessariamente a observância do princípio da igualdade, na sua manifestação de igualdade dos cidadãos perante os encargos públicos. Uma indemnização justa (na perspectiva do expropriado) será aquela que, repondo a observância do princípio da igualdade violado com a expropriação, compense plenamente o sacrifício especial suportado pelo expropriado, de tal modo que a perda patrimonial que lhe foi imposta seja equitativamente repartida entre todos os cidadãos.

Segundo o autor citado, o princípio da igualdade, como elemento normativo inderrogável que deve presidir à definição dos critérios de indemnização por expropriação, desdobra-se em duas dimensões ou em dois níveis fundamentais de comparação: o princípio da igualdade no âmbito da relação interna e o princípio da igualdade no domínio da relação externa da expropriação.

No campo da relação interna da expropriação, confrontam-se as regras de indemnização aplicáveis às diferentes Expropriações. Neste domínio, o princípio da igualdade impõe ao legislador, na definição de regras de indemnização por expropriação, um limite inderrogável: não pode fixar critérios de indemnização que variem de acordo com os fins públicos específicos das Expropriações (v.g., critérios de indemnização diferentes para as Expropriações de imóveis destinados a abertura de vias férreas, ao rasgo de auto-estradas, à execução dos planos urbanísticos, etc.), com os seus objectos (v.g. critérios diferenciados de indemnização para as Expropriações de imóveis e móveis, prédios rústicos e prédios urbanos, solos agrícolas e solos urbanizados, etc.) e com o procedimento a que elas se subordinam. 0 princípio da igualdade não permite que particulares colocados numa situação idêntica recebam indemnizações quantitativamente diversas ou que sejam fixados critérios distintos de indemnização que tratem alguns expropriados mais favoravelmente do que outros grupos de expropriados. Aquele princípio obriga o legislador a estabelecer critérios uniformes de cálculo da indemnização, que evitem tratamentos diferenciados entre os particulares sujeitos a expropriação.

No domínio da relação externa da expropriação, comparam-se os expropriados com os não expropriados, devendo a indemnização por expropriação ser fixada num montante tal que impeça um tratamento desigual entre os dois grupos. A observância do «princípio da igualdade dos cidadãos perante os encargos públicos» na expropriação por utilidade pública exige que esta seja acompanhada de uma indemnização integral (volle Entschädigung) ou de uma compensação integral do dano infligido ao expropriado. Aquele princípio impõe que a indemnização por expropriação possua um «carácter reequilibrador» em benefício do sujeito expropriado, objectivo que só será atingido se a indemnização se traduzir numa «compensação séria e adequada» ou, noutros termos, numa compensação integral do dano suportado pelo particular.

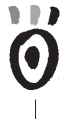


Na perspectiva de Alves Correia, o critério mais adequado ou mais apto para alcançar uma compensação integral do sacrifício patrimonial infligido ao expropriado e para garantir que este, em comparação com outros cidadãos não expropriados, não seja tratado de modo desigual e injusto, é o do valor de mercado (Verkehrswert), também denominado valor venal, valor comum ou valor de compra e venda do bem expropriado, entendido não em sentido estrito ou rigoroso, mas sim em sentido normativo.

Com a expressão "valor de mercado normativamente entendido», designa o autor «o valor de mercado normal ou habitual», não especulativo, isto é, um valor que se afasta, às vezes substancialmente, do valor de mercado resultante do jogo da oferta e da procura, já que está sujeito, frequentes vezes, a correcções, as quais são ditadas por exigências da justiça. Uma boa parte destas manifesta-se em reduções que são impostas pela especial ponderação do interesse público que a expropriação serve, como a eliminação dos elementos de valorização puramente especulativos e das mais-valias ou aumentos de valor ocorridos no bem expropriado, em especial nos terrenos, que tenham a sua origem em gastos ou em despesas feitas pela colectividade. Mas, noutros casos, aquelas traduzem-se em majorações, devido à natureza dos danos provocados pelo acto expropriativo.

Porque a resposta a esta questão envolve um juízo técnico, o Código das Expropriações fornece critérios específicos os quais, como decorre do que escrevemos, têm de ser entendidos, sob pena de inconstitucionalidade, como simples pontos de referência, destinando-se apenas à obtenção de um padrão de cálculo e sem intenção de pôr limites a justa indemnização.

É assim que o Código, adoptando aquilo que Alves Correia (Introdução ao Código das Expropriações e outra legislação sobre expropriações por utilidade pública, Lisboa, 1992) denomina de critério concreto de potencialidade edificativa, começa por distinguir entre solo apto para construção e solo para outros fins (art. $25 .^{\circ}, \mathrm{n} . .^{0} 1$ ), englobando no primeiro grupo (i)) o que dispõe de acesso rodoviário e de rede de abastecimento de água, de energia eléctrica e de saneamento, com características adequadas para servir as edificações nele existentes ou a construir; (ii)) o que apenas dispõe de parte das infra-estruturas referidas na alínea anterior, mas se integra em núcleo urbano existente; (iii)) o que está destinado, de acordo com instrumento de Gestão territorial, a adquirir as características descritas em i); (iv)) o, que, não estando abrangido pelo disposto nas alíneas anteriores, possua, todavia, alvará de loteamento ou licença de construção em vigor no momento da declaração de utilidade pública e desde que o processo respectivo se tenha iniciado antes da data da notificação a que se refere o n. ${ }^{\circ} 5$ do art. $10 .^{\circ}$. Solo apto para outros fins será todo aquele que não se encontra em qualquer uma das situações enunciadas (art. 25. \%/3).

Isto posto, resulta da Sentença recorrida que foi essential para a fixação da factualidade provada e da subsequente indemnização atribuída ao expropriado, proprietários da parcela expropriada, a avaliação a que se procedeu, obrigatória na fase judicial do processo de expropriação, face ao disposto no art. $.61^{1} \stackrel{0}{ }$, n.․․ 2, Cód. Exp.

Da leitura dos relatórios dos senhores peritos avaliadores resulta claro que TODOS consideraram o estado da parcela expropriada e a sua situação jurídica e respectiva potencialidade edificativa na data da DUP, ou seja considerando já, como não podia deixar ser, as implicações do Plano de Pormenor das Antas, instrumento de ordenação municipal do território que havia sido aprovado antes e que, portanto, estava em pleno vigor na data da DUP relativa à presente expropriação.

Esta expropriação resulta, aliás, da necessidade de executar tal Plano, certamente na falta de acordo entre a autarquia e o expropriado, conforme prescrevem os artigos $90^{\circ} \mathrm{a}$ $92^{\circ}$ e $118^{\circ} \mathrm{ss}$, maxime art $^{\circ} 128^{\circ}$, todos do DL n. $380 / 99$, de 22.09 , que desenvolve as bases da política de ordenamento do território e urbanismo, vigente na data da DUP. 
Refira-se que no laudo da decisão arbitral também assim se considerou.

Com vista à fixação da justa indemnização devida pela expropriação, TODOS os senhores peritos avaliaram a parcela expropriada à luz desse Plano de Pormenor, já devidamente em vigor e em fase de execução e procederam ao cálculo da indemnização a luz do critério referencial resultante dos artigos $26^{\circ}$ e $28^{\circ} \mathrm{CE}$ e à luz do critério do valor de mercado, fazendo apelo ao disposto no art. $23^{\circ}, n .^{\circ}$, CE, tendo optado pela fixação nos seus laudos dos valores de mercado acima referidos expressos nos relatórios a fls. 381 (nomeado pelo expropriante), 405 (nomeados pelo tribunal) e a fls. 418 (nomeado pelo expropriado), tendo sido indicados, respectivamente, os seguintes valores para a justa indemnização pela expropriação da parcela em causa: $€$ 455.700,00, $€$ 503.568,00 e $€$ 1.000.000,00.

Deve salientar-se que os senhores peritos indicados pelo tribunal e, pelo expropriado são todos engenheiros civis e o perito indicado pela expropriante é licenciado em Gestão Imobiliária e docente da ESAl, ou seja todos são técnicos com conhecimentos idóneos para proferirem um juízo eminentemente técnico sobre a avaliação da parcela expropriada, conhecimentos que não são, nem têm que ser exigíveis aos juízes.

A avaliação constitui, assim, na fase judicial litigiosa do processo de expropriação, tal como vem definida na nossa actual ordem jurídica, a diligência probatória fundamental para que o tribunal, depois de proceder a sua análise crítica e ao juízo de conformidade à lei, decidir da fixação da justa indemnização devida a quem vê sacrificada o seu património ou encargos autónomos à satisfação do chamado "bem comum".

Questões relacionadas com o acto administrativo que declara a utilidade pública da expropriação, que não sejam incidentais do processo judicial de expropriação litigiosa, devem ser resolvidas no foro administrativo, por força do disposto nos art.s $211^{\circ}$, n. $01 \mathrm{e}$ $212^{\circ}$, n. ${ }^{\circ}$, da Constituição da República Portuguesa de 1976 e art.s $1^{\circ}$, n. ${ }^{\circ} 1$ e $4^{\circ}$, al. c) do ETAF, aprovado pela Lei $n .0_{13 / 02}$, de 19.02 .

Isto posto, conforme resulta da Sentença recorrida, esta, após ter procedido a uma análise crítica dos diversos laudos periciais, acabou por concluir que o laudo maioritário dos peritos do tribunal era aquele que deveria seguir para indemnizar o expropriado e, nessa perspectiva, aderiu in totum ao relatório de avaliação dos referidos peritos.

Porque aquele laudo se encontra devidamente fundamentado, considerando a factualidade que importa para a fixação da indemnização devida, e dado que estes peritos não foram indicados pelas partes, antes pelo tribunal de forma aleatória da lista oficial de peritos, também nós não vemos razão para censurar a decisão proferida, a qual utilizando o critério do valor de mercado com base na "válvula de escape" que confere o art. ${ }^{\circ} 23^{\circ}$, n.. 5, CE, leva a atribuir uma indemnização mais adequada com a realidade económica da parcela expropriada à data da DUP.

Da devida leitura da Sentença e da sua interpretação de acordo com a impressão de um declaratário normal, não é legítimo retirar a interpretação, que o apelante retira nas conclusões de recurso, de que "tratando-se de uma expropriação para a execução de um plano de pormenor, já aprovado ao tempo da declaração de utilidade pública - como é o caso dos presentes autos -, o valor de mercado a atender no cálculo da justa indemnização deve referir-se à situação que existia antes desse plano ou, pelo contrário, porque esse plano já vigorava e produzia efeitos ao tempo da declaração de utilidade pública, esse valor e indemnização devem reflectir as soluções desse plano de pormenor?

(...) O expropriado defende que o valor de mercado a aplicar neste processo expropriativo não pode deixar de ser o que atende as soluções do Plano de Pormenor das Antas (PPA), já executadas ou com execução programada, pelo que deverá ser adoptado o Relatório de Avaliação subscrito pelo Perito Eng. ... e não os valores calculados pelos Peritos indicados pelo Tribunal. Trata-se de uma das regras mais consensuais Direito das Expropriações que vincula o cálculo indemnizatório". 
Isto porque, em lado algum da sentença e do relatório pericial maioritário se expressa o entendimento de que o valor de mercado a atender no cálculo da justa indemnização deve referir-se à situação que existia antes desse plano.

Improcede, assim, o primeiro fundamento do recurso e prejudicada fica a questão da pretensa inconstitucionalidade material da norma do $\operatorname{art}^{\circ} 23^{\circ}, n .{ }^{\circ} 1$, Código das Expropriações, levantada pelo apelante.

Quanto à indemnização pelos prejuízos resultantes do período de paralisação e reinstalação da actividade industrial exercida na parcela expropriada (artigo 31ํㅡ, n.ํㅜ 1, do Código das Expropriações), entende o expropriado que "também quanto a esta dimensão indemnizatória, deverá este douto Tribunal adoptar a avaliação efectuada pelo Perito Eng. ..., tanto mais que nenhuma das outras avaliações constantes dos autos o fez. Assim, um valor indemnizatório de $€ 20.000$ (no sentido de ser devida esta indemnização, o Acórdão deste douto Tribunal de 19.01.1993, Processo n.ำ9210518, www.dgsi.pt, citado na pág. 22 das alegações do expropriado).

Para que houvesse direito de indemnização por prejuízos colaterais ou derivados que sejam consequência directa e necessária da expropriação sempre teria o expropriado o ónus de os provar em concreto e o respectivo nexo de causalidade adequada - vide Ac. Tribunal Constitucional n.ำ 231/08, DR 2 Série, n.ำ140, 22.07.2008.

Ora, na sentença recorrida deu-se como provado, no facto 28 , que na cave da moradia expropriada existe maquinaria destinada à actividade de ourivesaria. Não ficou provada matéria suficiente de onde resulte que o expropriado ali tinha efectivamente instalado um estabelecimento industrial de ourivesaria e que tivesse cessado essa sua actividade ou alterado a sua localização, daí derivando não prejuízos emergentes da presente expropriação.

Ao expropriado cabia em devido tempo, nas Alegações de recurso do acórdão arbitral o ónus da alegação e, na instrução do processo, o ónus da prova desses factos essenciais à sua pretensão indemnizatória - $\operatorname{art}^{\circ} 342^{\circ}, \mathrm{n} .{ }^{\circ} 1$, Código Civil, o que não logrou fazer.

Não poderá o esclarecimento de fls. 569 do perito indicado pelo expropriado ser considerado idóneo para tal prova, dado o seu carácter meramente especulativo e não "científico" nessa matéria, aliás em contradição com o seu parecer negativo contido na parte final do seu laudo pericial (fls 427).

Da Vistoria ad perpetuam rei memoriam - cfr. fl. 24 dos autos, bem como os respectivos Anexos II e III, a fls. 96-97 do processo da Câmara Municipal apenso aos autos também não resulta a efectiva existência e exploração na cave da moradia expropriada de estabelecimento industrial de ourivesaria pelo expropriado na data da DUP.

Pretende, finalmente, o expropriado, ser indemnizado "pelos custos que o Expropriado terá com a mudança da sua residência para um outro local e que se estimam, pelo menos, em $€ 6.500$ (cfr. Documento junto aos Esclarecimentos prestados pelo Eng. ..., a fl. 570 dos autos), bem como o valor do IMT que o Expropriado terá que suportar na aquisição de uma nova moradia deste valor ( $6 \%$ do valor da aquisição - cfr. art. $17^{\circ}, n^{\circ}$ s. 1 e 2, do CIMT)".

Ora, as considerações anteriores são também aqui aplicáveis, sendo certo que nesta matéria o expropriado apenas assenta a sua pretensão na "opinião" do perito por si indicado, aquando da resposta aos esclarecimentos que lhe pediu.

Relativamente a estes danos, entendemos que não tem justificação no âmbito da justa indemnização devida aos expropriados, porquanto não traduzem ressarcimento de qualquer prejuízo directo para estes da própria expropriação, não estando demonstrado que o expropriado necessite de adquirir outra habitação já construída ou a construir, que está ou não isenta essa eventual aquisição total ou parcialmente de impostos, de emolumentos notariais ou do registo e que não opte pelo arrendamento ou outra forma jurídica de habitação.

Assim, o valor indemnizatório a considerar, retirados factores meramente especulativos, é o que resulta do laudo dos peritos do tribunal, como foi acolhido na Sentença e com o qual o expropriante se conformou, como resulta das contra alegações de recurso apresentadas. 
Diga-se que esse valor indemnizatório, conforme foi decidido na Sentença, será actualizado nos termos legais até ao presente acórdão, de acordo com o disposto no art $24^{\circ}$, n.- ${ }^{-} 1$ e 2, Código das Expropriações de 1999 e atendendo-se a que os índices de inflação se aplicam cada um de per si sobre o apuramento emergente da taxa anterior, não se somando.

Esta interpretação jurisprudencial foi acolhida pelo Acórdão Uniformizador de Jurisprudência n. ${ }^{\circ}$ 7/2001 proferido pelo Supremo Tribunal de Justiça (DR, I- Série, de 25 de Outubro de 2001), o qual embora proferido relativamente às normas do $\operatorname{art}^{\circ} 23^{\circ}, \mathrm{n}^{\circ} \mathrm{S} 1 \mathrm{e} 2$, Código

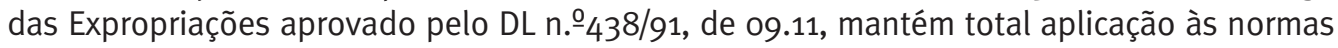
do $\operatorname{art}^{\circ} 24^{\circ}, n^{\circ} \mathrm{S} 1$ e 2, Código das Expropriações de 1999, dado que tem o mesmo conteúdo.

Em conformidade, pela presente expropriação o expropriado recebeu já, através de levantamentos efectuados nos autos, o montante de $€ 545 \cdot 590,37$.

\section{III- DECISÃO:}

Pelo exposto, acordam os juízes deste Tribunal da Relação do Porto em julgar improcedente a presente apelação e, em consequência, confirmar a Sentença recorrida.

\section{Comentário}

\section{Considerações introdutórias}

A selecção do presente aresto para comentário teve como intenção, mais do que analisar o caso concreto que trata, discutir a questão que genericamente dele decorre: a de saber se "tratando-se de uma expropriação para a execução de um plano de pormenor já aprovado ao tempo da declaração de utilidade pública (...), o valor de mercado a atender no cálculo da justa indemnização deve referir-se à situação que existia antes desse plano ou, pelo contrário, porque esse plano já vigorava e produzia efeitos ao tempo da declaração de utilidade pública, esse valor e indemnização devem reflectir as soluções desse plano de pormenor?"

Precisando os dados com relevo para as reflexões a que aqui iremos proceder, em causa está, em primeiro lugar, uma expropriação para execução de um plano municipal (que a doutrina designa de expropriação acessória ao plano) 3 .

Tal plano municipal é, em segundo lugar, um plano de pormenor, que é aquele que se apresenta, atenta a área territorial de abrangência e o seu conteúdo material, como o plano municipal mais concreto, uma vez que procede a uma exaustiva definição da situação fundiária da área de intervenção, actuando sobre ela e permitindo, quando necessário, proceder à sua transformação. ${ }^{4}$ Daqui decorre o terceiro dado com relevo: o plano de pormenor aqui

\footnotetext{
${ }_{3}^{3}$ Sobre esta designação cfr. Fernando Alves Correia, Manual de Direito do Urbanismo, Vol. II, Coimbra, Almedina, 2010, pp. 131 e ss.

4 Pela sua caracterização, o plano de pormenor é aquele que tem maiores consequências na conformação do território e do direito de propriedade dos solos sobre que incide. Esta dimensão constitutiva e conformadora é confirmada pelo disposto no Regime Jurídico da Urbanização e Edificação, que, nos termos do seu artigo 4.ํㅜ, sujeita ao procedimento da comunicação prévia a realização de operações urbanísticas a realizar nas áreas abrangidas por plano de pormenor que contenha a maioria das menções previstas no artigo 91.ํ do RJIGT [alínea c) do n. 4 ], o qual é mesmo desnecessário quando a este forem conferidos efeitos registais.
} 
em causa visa proceder à transformação da situação fundiária preexistente, pelo que a sua execução passará necessariamente pela concretização de uma operação de reparcelamento. Tal sucede (e é assim na esmagadora maioria dos casos), sempre que o plano de pormenor aponta para um desenho urbano "desligado" da situação fundiária da sua área de intervenção, propondo uma solução urbanística que, para ser concretizada, obriga à transformação daquela.

Note-se que, por a operação de reparcelamento se apresentar como uma operação urbanística, a mesma apenas poderá ser concretizada se estiver verificada a necessária legitimidade, o que significa que, se não é necessário o consentimento dos proprietários para que o plano desenhe uma solução urbanística que não respeita a situação fundiária existente, já o consentimento da totalidade dos mesmos é indispensável para a concreta operacionalização do reparcelamento, sendo fundamental para o efeito a celebração de contratos entre os proprietários e/ou outras entidades interessadas - contratos de urbanização - ou destes com a Administração - contratos de desenvolvimento urbano -, nos termos dos quais se definem os direitos e encargos de cada um na operação, bem como a distribuição dos lotes ou parcelas resultantes da mesma.

$\mathrm{Na}$ eventualidade de algum deles manifestar o seu desacordo em relação à operação de reparcelamento que executa o plano, o processo apenas poderá avançar mediante o desencadeamento de um procedimento expropriativo. No entanto, nem sempre o recurso à via expropriativa é admissível, estando a mesma dependente do sistema de execução que tiver sido adoptado pelo plano (e respectiva fundamentação). Assim, se o sistema for o de compensação - o qual deve ser reservado para operações que embora admissíveis, não fazem parte da ordem de prioridades do município - está afastada a expropriação, o que significa que se não se alcançar a associação entre todos os proprietários, a operação não pode ser realizada 5 .

Diferente será a situação no caso do sistema de cooperação e do sistema de imposição administrativa. 0 primeiro é adoptado quando estejam em causa operações desejáveis, disponibilizando-se a administração para, por via da expropriação, substituir os proprietários que se não queiram associar e, assim, garantir a sua concretização. 0 da imposição deve ser adoptado quando se trate de intervenções que, nos termos do plano, assumam uma prioridade absoluta, o que justifica o recurso à expropriação, embora esta opção não deva, em nome do princípio da proporcionalidade, fechar as portas à possibilidade de se poder promover a intervenção urbanística pelos interessados. ${ }^{6}$ Isto porque o sistema de imposição administrativa não corresponde a um sistema de expropriação sistemática e não há, sequer, qualquer contradição entre o recurso ao sistema de imposição administrativa e a ausência de expropriação. É o que sucederá quando, tendo os proprietários dificuldades em assegurar, em tempo útil, a execução do plano, contratualizam com o município a direcção de todo o processo (programação e promoção - directamente ou por via de concessão de

\footnotetext{
${ }_{5}^{5}$ Este deverá ser o sistema a adoptar naquelas situações em que para a Administração municipal não é prioritário que uma determinada área do seu território, embora tal seja admitido pelos planos em vigor, venha a ser objecto de intervenções urbanísticas, permitindo, contudo, que as mesmas possam ocorrer desde que realizadas em parceria pelos vários proprietários abrangidos pelo plano. Ou seja, embora não desejada a sua ocorrência, o município admite intervenções urbanísticas de conjunto, empurrando, nestes casos, o plano de pormenor, os proprietários para processos associativos, sem que a Administração se proponha substituir aqueles que não se queiram associar. Com estas condições, o mais certo é que a operação de reparcelamento prevista no plano de pormenor não venha a ocorrer (basta que um dos proprietários se oponha); no caso, porém, de tal associação se verificar, o município conseguirá, no mínimo, que ela se realize nos termos pretendidos (definidos no plano). Neste sentido vide Jorge Carvalho, Ordenar a Cidade, Coimbra, Quarteto, 2003, pp. 413-414.

${ }^{6}$ Assim, sempre que existe uma área em que importa intervir de uma forma integrada e com uma solução de conjunto, de forma a prosseguir um interesse público imediato (v.g. a abertura de uma via estruturante), a adopção do sistema de imposição significa que, caso os proprietários se não associem para realizar a operação urbanística conjunta - reparcelamento ou loteamento conjunto - num determinado prazo (no âmbito da qual cederão para o domínio público municipal os terrenos a afectar àquela via e, eventualmente, a executarão), a Administração se substituirá a estes de modo a garantir a realização da infra-estrutura viária em causa.
} 
urbanização - da execução do plano), cedendo os seus terrenos para integrarem a "massa de concentração" da operação de reparcelamento e recebendo, posteriormente, os lotes ou parcelas dele resultantes na proporção das respectivas "entradas", descontados os encargos que não assumiram (caso não os tenham assumido).

A adopção do sistema de imposição como um sistema de expropriação sistemática ou como um sistema que exclui logo à partida um conjunto de proprietários prevendo a respectiva expropriação independentemente da vontade destes em aderir à operação de reparcelamento prevista no plano, apenas deve ser admitida excepcionalmente e desde que devidamente fundamentada, de forma a comprovar a proporcionalidade desta opção e que a mesma é o resultado de uma justa ponderação de todos os interesses envolvidos. E isto porque o reparcelamento corresponde, em regra, à operação de transformação fundiária que termina com a adjudicação dos lotes ou parcelas aos primitivos proprietários, pelo que a exclusão de alguns deles (ou de todos) da operação de reparcelamento, através da expropriação dos seus prédios, apenas deve ocorrer quando estes manifestem o seu desacordo relativamente ao projecto de reparcelamento (cfr. $n . .7$ do artigo 131. 0 do Regime Jurídico dos Instrumentos de Gestão Territorial, doravante RJIGT7) ou quando existam motivos de interesse público, os quais devem ser devidamente explicitados, que o justifiquem.

Fazemos aqui particular referência a este facto porque, em nosso entender, e como melhor veremos mais adiante, a resposta à questão central constante do Acórdão aqui em anotação deve ser diferenciada consoante a expropriação se fique a dever a uma oposição do proprietário em aderir à operação de reparcelamento que executa o plano ou a uma sua exclusão do processo contra a sua vontade.

\section{A justa indemnização no Código das Expropriações}

Uma vez que a questão central sobre a qual nos propomos reflectir no presente Acórdão se prende com a determinação da justa indemnização no âmbito de um procedimento expropriativo, comecemos, ainda que de forma sumária, por referir alguns pontos de relevo a propósito dela, a qual é assumida, por força do disposto no n.․․ 2 do artigo $62 .$. da Constituição da República Portuguesa, como um pressuposto de legitimidade do acto expropriativo e simultaneamente como um elemento integrativo do mesmo ${ }^{8}$.

O Tribunal Constitucional tem vindo, ao longo dos anos, a densificar, na sua jurisprudência, este conceito jurídico, dela decorrendo que a justa indemnização é aquela que visa compensar o sacrifício suportado pelo expropriado e garantir a observância do princípio fundamental da igualdade de encargos que tenha sido violada com a expropriação', apresentando-se, assim, como uma reconstituição, em termos de valor, da posição jurídica que o expropriado detinha.

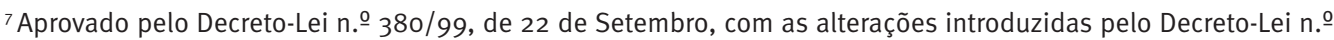
53/2000, de 7 de Abril, pelo Decreto-Lei n. ${ }^{\circ}$ 310/2003, de 10 de Dezembro, pela Lei n.ํ5ㅇ 2005 , de 29 de Dezem-

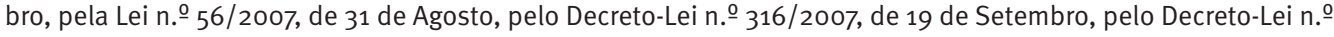
46/2009, de 20 de Fevereiro, e pelo Decreto-Lei n.ำ181/2009, de 7 de Agosto

${ }^{8} \mathrm{Cfr}$., sobre esta questão, Fernando Alves Correia, A Jurisprudência do Tribunal Constitucional sobre Expropriações por Utilidade Pública e o Código das Expropriações de 1999, in Separata da «Revista de Legislação e Jurisprudência», Ano $132^{\circ}$, N. ․ㅗ 3905 e 3906 e Manual de Direito do Urbanismo, cit., pp. 209 e ss, que aqui seguiremos muito de perto. 9 Para este Tribunal o respeito pelo princípio da igualdade deve ser entendido quer no sentido de que as regras da indemnização aplicáveis aos diferentes tipos de expropriação devem tratar de um modo igual os vários sujeitos expropriados (princípio da igualdade na relação interna da expropriação) quer no sentido de que, analisando-se comparativamente as situações jurídico-patrimoniais dos proprietários expropriados e dos proprietários não expropriados, os critérios da indemnização devem possibilitar um tratamento jurídico igual entre aqueles dois grupos de cidadãos (princípio da igualdade na relação externa da expropriação).
} 


\section{RerCED光UA

Ainda de acordo com a ampla jurisprudência do Tribunal Constitucional, a justa indemnização é aquela que corresponde ao valor adequado que permita ressarcir o expropriado da perda que a transferência do bem que lhe pertencia para outra esfera dominial lhe acarreta, devendo ter-se em atenção, na sua fixação, a necessidade de respeitar o princípio da equivalência de valores: nem a indemnização deve ser tão reduzida que o seu montante se torne irrisório ou meramente simbólico nem, por outro lado, nela deve atender-se a quaisquer valores especulativos ou ficcionados, de forma a distorcer, (positiva ou negativamente) a necessária proporção que deve existir entre as consequências da expropriação e a sua reparação.

No conceito constitucional da justa indemnização está, porém, também implícita uma justiça do ponto de vista do interesse público que a expropriação visa prosseguir, motivo pelo qual se admitem cláusulas de redução com a finalidade de dela "eliminar (...) elementos de valorização puramente especulativos e mais-valias ou aumentos de valor que tenham a sua origem na própria declaração de utilidade pública da expropriação."

De modo a dar cumprimento a estas exigências constitucionais, o legislador ordinário fixou, no artigo 23. do Código das Expropriações (CE), que a justa indemnização “...não visa compensar o benefício alcançado pela entidade expropriante, mas ressarcir o prejuízo que para o expropriado advém da expropriação, correspondente ao valor real e corrente do bem de acordo com o seu destino efectivo ou possível numa utilização económica normal, à data da publicação da declaração da utilidade pública, tendo em consideração as circunstâncias e condições de facto existentes naquela data", norma da qual decorre, segundo a doutrina mais representativa, que a justa indemnização corresponde ao valor de mercado: valor venal ou valor de compra e venda, isto é, a quantia que teria sido paga pelo bem se este tivesse sido objecto de livre contrato de compra e venda, descontados os valores especulativos.

Para este efeito, o Código das Expropriações, seguindo de perto a jurisprudência do Tribunal Constitucional, classifica os solos em aptos para construção e para outros fins: nos primeiros atenta-se a elementos certos e objectivos ${ }^{10}$; nos segundos integram-se todos os restantes solos.

A lei não deixou de considerar, porém, nos termos supra referidos, a necessidade de a justa indemnização ter em conta o interesse público que com a expropriação se pretende prosseguir. É por isso que, nos termos do Código das Expropriações, não pode tomar-se em consideração, na determinação do valor dos bens expropriados, as mais-valias que resultarem da própria declaração de utilidade pública; de obras ou empreendimentos públicos concluídos há menos de cinco anos, no caso de não ter sido liquidado encargo de mais-valias e na medida deste ${ }^{11}$; de benfeitorias voluptuárias ou úteis ulteriores à notificação da resolução de expropriar; e de informações de viabilidade, licenças ou autorizações administrativas também ulteriores àquela notificação (artigo 23.ํ, n.ำ 2). Na fixação da indemnização não são também considerados quaisquer factores, circunstâncias ou situações criadas com o propósito de aumentar o valor do bem (artigo 23.. , n. .93 ).

É por este motivo que se afirma que, se bem que o critério para a determinação do conceito de justa indemnização seja o do valor de mercado (valor venal, comum ou de compra e venda) do bem expropriado, o mesmo não pode ser entendido em sentido estrito

\footnotetext{
${ }^{10}$ Espelhados na dotação do solo em infra-estruturas urbanísticas [artigo 25.ำ, n.ํㅡ 2 alínea a)], na sua inserção em núcleo urbano [artigo 25.ำ n.ํㅜㄹ a alínea b)], na qualificação do solo como área de edificação em plano municipal de ordenamento do território [artigo $25 . \stackrel{\circ}{ }, \mathrm{n} . .^{\circ}$ 2, alínea c)] ou na cobertura do mesmo por alvará de loteamento ou de licença de construção em vigor no momento da declaração da utilidade pública, desde que o processo respectivo se tenha iniciado antes da data da notificação da resolução de expropriar referida no artigo 10.ำ do Código das Expropriações [artigo 25.ํㅜ n. $\stackrel{\circ}{2}$, alínea d)].

${ }^{11} \mathrm{~A}$ não consideração das mais-valias resultantes de obras ou empreendimentos públicos só tem lógica quando a entidade beneficiária da expropriação tiver sido a entidade responsável pela realização de tais obras ou empreendimentos, caso contrário, esta exclusão não tem razão de ser.
} 
mas em sentido normativo, precisamente por ditar a necessidade de efectuar reduções impostas pela especial ponderação do interesse público que a expropriação serve, bem como majorações devido à natureza dos danos provocados pelo acto expropriativo.

Esclarecido, de forma sumária, o sentido do conceito de justa indemnização, incidamos agora a nossa atenção sobre a questão que é genericamente colocada no Acórdão aqui em anotação.

\section{0 valor da indemnização: valor da parcela antes do plano ou de acordo com as opções dele constantes?}

Resulta, do que foi referido, não poder (não dever) ser contabilizado no montante da indemnização a mais-valia que resulta da declaração de utilidade pública, isto é, a valorização que é introduzida no terreno pelo próprio projecto expropriante (o projecto que fundamenta a expropriação) - cfr. artigo 23.ํ, n.. 2 , alínea a) do CE. Isto porque a indemnização não serve para compensar o benefício alcançado pela entidade expropriante, mas tão-somente ressarcir o prejuízo que para o expropriado advém da expropriação (cfr. n. -1 do artigo $23.0^{\circ}$ do CE).

Não se pode, contudo, ignorar o disposto no n. .1 do artigo $23 .$. e n. 1 do artigo $24 . .^{\circ}$ do CE, segundo os quais é o momento da declaração de utilidade pública aquele que é relevante para a determinação do valor dos bens, devendo por isso ter-se em consideração as circunstâncias e condições de facto do bem a essa data. Ora, é sabido que o valor dos solos depende daquilo que neles pode ser feito, que, por sua vez, depende, essencialmente, dos instrumentos de planeamento em vigor à data da declaração de utilidade pública. De onde decorre, como consequência natural, que se deva ter em consideração, para efeitos da determinação do montante da indemnização, o que prescrevem para a área tais instrumentos planificadores.

Acresce que, correspondendo os vários instrumentos de planeamento municipal (plano director municipal, plano de urbanização e plano de pormenor) a graus de intervenção diferenciada sobre o território - sucessivamente mais concretos e precisos - , se uma área se encontrar simultaneamente abrangida por vários deles, as decisões que em cada momento tenham de ser tomadas deverão ter como referência o instrumento de planeamento em vigor mais preciso. E isto porque existe, na gestão urbanística - isto é, nas decisões sobre a concreta ocupação do território que sejam feitas a partir dos instrumentos de planeamento - , um princípio da maior proximidade do instrumento de planeamento aplicável: estando a área simultaneamente abrangida, por exemplo, por um plano director municipal e por um plano de pormenor, é a este que as entidades terão de se ater quanto às decisões a tomar na sua área de abrangência e é este que define, em concreto, o que podem ou não fazer os proprietários abrangidos. Motivo pelo qual terá de se concluir que na determinação do montante da indemnização devida pela expropriação dos solos integrados num plano de pormenor para efeitos da sua execução se terá de atender às soluções urbanísticas dele constantes para a parcela em causa.

Entendemos, porém, que esta não é a solução mais adequada em todos os casos, se se tiver em consideração o conceito de justa indemnização antes referido.

Assim, e desde logo, não pode esquecer-se que muitos planos de pormenor assumem um grau de precisão e concretização tais que correspondem, eles mesmos, a verdadeiros projectos (planos de pormenor referidos a projectos).

É o que sucede com aqueles planos de pormenor que identificam com tal precisão a transformação da situação fundiária, que o projecto de reparcelamento que vier a concretizar-se para a sua execução nada traz de novo em relação a ele, repetindo, por isso, tudo quanto consta já, de forma precisa, do plano de pormenor. É aliás a planos de pormenor com este conteúdo preciso que a lei permite que se atribuam efeitos registais, o 


\section{RerCED光UA

que significa que são conferidos a estes planos os efeitos da aprovação ou licenciamento da operação de reparcelamento, já que se opera, com o registo do plano, a transformação da situação fundiária. Precisamente por isso, o registo do plano de pormenor dispensa o posterior licenciamento ou aprovação das operações de loteamento/reparcelamento envolvidas (cfr. artigo $131 . \stackrel{0}{n} .{ }^{\circ} 10$ do RJIGT) ${ }^{12}$.

Referidos a projectos são também os planos de pormenor elaborados para a concretização do Programa Polis, programa destinado a melhorar a qualidade de vida nas cidades, através de intervenções nas vertentes urbanística e ambiental, com vista a melhorar a atractividade e competitividade de pólos urbanos que têm um papel relevante na estruturação do sistema urbano nacional. Por esse motivo, as grandes intervenções deste Programa são ao nível dos projectos já que os seus objectivos são os de desenvolver grandes operações integradas de requalificação urbana com uma forte componente de valorização ambiental bem como acções que contribuam para a requalificação e revitalização de centros urbanos e que promovam a multifuncionalidade desses centros; apoiar outras acções de requalificação que permitam melhorar a qualidade do ambiente urbano e valorizar a presença de elementos ambientais estruturantes tais como frentes de rio ou de costa; e patrocinar iniciativas que visem aumentar as zonas verdes, promover áreas pedonais e condicionar o trânsito automóvel em centros urbanos.

Na Resolução do Conselho de Ministros n. 26/2000, de 15 de Maio, que criou o Programa Polis, prevê-se a adopção de "instrumentos que garantam a eficácia da sua execução e a coerência dos seus propósitos", designadamente instrumentos de intervenção urbanística, empresariais e de protocolarização com os municípios. De entre os instrumentos de intervenção urbanística (os que aqui interessam), prevê-se a elaboração de planos estratégicos, planos de urbanização, quando a área o justifique, e de planos de pormenor a elaborar pela entidade promotora e gestora do projecto.

E embora nestes dois últimos casos (com especial relevo para os planos de pormenor, os mais utilizados) estejam em causa instrumentos de planeamento, a verdade é que os mesmos enquadram projectos muito concretos, precisamente os referentes às operações e aç̧ões destinadas à requalificação urbana e valorização ambiental.

Poderia perguntar-se porque razão a Resolução do Conselho de Ministros n.ำ 26/2000 aponta, como instrumentos de intervenção urbanística, apenas os planos e não já as operações urbanísticas concretas, designadamente, de loteamento urbano, questionando-se o que é possível alcançar por aquela via que não fosse alcançável por esta.

A resposta, quanto a nós, é fácil e prende-se com a legitimidade para intervir nos solos: enquanto uma operação de loteamento pressupõe a elaboração de um projecto que terá de ser apresentado pelos titulares (por todos os titulares) de direitos sobre os solos; o plano de pormenor, como instrumento de planeamento de iniciativa e responsabilidade pública, não a pressupõe. A aprovação do projecto por intermédio de um plano de pormenor é, assim, a forma de, de um modo sustentado, se poder lançar do expediente das expropriações como forma de aquisição dos solos e, deste modo, de aquisição da legitimidade para sobre eles intervir concretizando os projectos de valorização urbanística e ambiental no caso de os proprietários se oporem à sua concretização.

Isto é, com a aprovação do plano possibilita-se, de forma mais fundamentada, o recurso à expropriação como mecanismo para a aquisição dos solos onde será concretizado o projecto que aquele plano integra.

\footnotetext{
${ }_{12}$ Sobre a identidade de função dos planos de pormenor com efeitos registais e das operações de loteamento/reparcelamento urbano, em especial quando integradas em unidades de execução cfr. o nosso "As Virtualidades das Unidades de Execução num Novo Modelo de Ocupação do Território: Alternativa aos Planos de Pormenor ou outra via de Concertação de Interesses no Direito do Urbanismo?" in Direito Regional e Local, n. ํㅡㄹ, Abril/Junho, 2008, p. 17 e ss.
} 
Ora, partindo desta realidade - isto é, da existência de planos de pormenor referidos a projectos - teremos de concluir que, tornando-se necessário proceder a uma expropriação para a sua execução, é o próprio plano que se apresenta como o projecto expropriante; aquele cujas mais-valias não podem ser tidas em consideração para efeitos da determinação cálculo da indemnização, segundo a alínea a) do $\mathrm{n} . \stackrel{0}{2}$ do artigo $23 .{ }^{\circ}$ do $\mathrm{CE}^{13}$.

E é a desconsideração, nestes casos, para efeitos da determinação do montante da indemnização, da opção constante do plano, a única solução que permite dar cumprimento ao disposto no n.․ 1 do artigo 23.-: de que a indemnização apenas deve ressarcir os prejuizos que para o expropriado advêm da expropriação, não se destinando a compensar o benefício alcançado pela entidade expropriante com o projecto expropriativo ${ }^{14}$.

Para além do argumento que decorre da alínea a) do n.으 2 do artigo 23. do CE, existem ainda outros que apontam no mesmo sentido - de desconsideração da valorização decorrente do projecto consubstanciado, nas situações a que nos vimos referindo, no plano de pormenor, cuja execução implicará a concretização de uma operação de reparcelamento.

Estes argumentos devem ser buscados no RJIGT, precisamente o diploma que regula algumas das mais importantes questões atinentes à execução dos planos municipais, entre os quais se contam os planos de pormenor.

Com efeito, uma leitura atenta do disposto no artigo $132 .^{\circ}$ do RJIGT permite perceber que uma coisa é a avaliação das parcelas à data do início do processo, outra, distinta, a sua avaliação após a concretização da operação. Como decorre expressamente do n.․ 1 do artigo 132.. , no âmbito de uma operação de reparcelamento, os benefícios que terão de ser, in fine, distribuídos a cada proprietário, hão-de ser proporcionais "ao valor do respectivo terreno à data do início do processo", o que significa que nessa avaliação não se tem em consideração (não se pode ter em consideração) a valorização que nos mesmos será introduzida pelo projecto de reparcelamento (que é, nos casos a que nos vimos referindo, o projecto que consta do próprio plano de pormenor e que será concretizado através da operação de reparcelamento ou directamente com o registo do plano). 0 que está em plena consonância com o disposto no Código das Expropriações, que manda atender ao valor do bem à data da declaração de utilidade pública, não se contabilizando mais-valias dela resultantes, isto é, as mais-valias que serão introduzidas nos terrenos expropriados por força do projecto expropriante.

Do afirmado até ao presente momento resulta aquela que, a nosso ver, deve ser a resposta à questão genericamente colocada no acórdão aqui em anotação: na determinação do valor da indemnização de parcelas necessárias à execução de um plano de pormenor do tipo a que nos vimos referindo, já aprovado ao tempo da declaração de utilidade pública, apenas se deve ter em consideração a sua aptidão inicial (isto é, antes do plano de pormenor), e não a que resulta das soluções (opções de ocupação territorial) do projecto constante deste instrumento de planeamento territorial. Uma solução distinta significaria a violação do critério constitucional da justa indemnização, ressarcindo-se o expropriado de um valor que ele não tinha e que apenas é introduzido no bem por força do projecto que justifica a expropriação $0^{15}$.

\footnotetext{
${ }_{13}^{13}$ Do mesmo modo que não deve considerar-se, no montante da indemnização, as mais-valias resultantes do plano enquanto "projecto expropriativo" (por exemplo, o plano prevê a implantação, numa unidade predial não dotada de qualquer infra-estrutura, de vários lotes devidamente infraestruturados), também não deve atender-se à menos valia (ou desvalorização) dele resultante (por exemplo, para uma área dotada, de acordo com o plano director municipal em vigor, de capacidade edificativa, o plano de pormenor, por motivos de ordenamento, impede numa parcela aí integrada, qualquer edificabilidade).

${ }^{14}$ Expressamente no sentido de se não ter em conta o previsto no Plano de Pormenor das Antas na determinação do valor da expropriação de uma parcela para efeitos da execução daquele instrumento de planeamento por estar em causa a mais-valia resultante da própria expropriação cfr. Acórdão da Relação do Porto, Processo n.ำ 6740/08-2, de 3 de Fevereiro de 2009. ${ }^{15}$ Era neste sentido que dispunha o n. -2 do artigo $24 .{ }^{\circ}$ do Decreto-Lei n. $.9104 / 2004$, de 7 de Maio, nos termos do qual, no âmbito da reabilitação urbana "O montante da indemnização calcula-se com referência à data declaração de utilidade pública e deve corresponder ao valor real e corrente dos imóveis expropriados no mercado, sem contemplação das mais-valias resultantes de reabilitação da zona de intervenção"(sublinhado nosso).
} 


\section{Uma precisão na tese defendida}

Julgamos, porém, que esta solução apenas deve valer sem quaisquer reservas naquelas situações em que a expropriação visa superar a falta de acordo do proprietário na concretização da operação de reparcelamento que executa o plano de pormenor. Esta é, aliás, a única situação em que o RJIGT se refere à admissibilidade de expropriar os proprietários dos solos para efeitos de concretização de uma operação de reparcelamento.

Com efeito, o que determina $\mathrm{n} .-7$ do artigo 131. - do RJIGT é que "Sempre que algum ou alguns dos proprietários manifestem o seu desacordo relativamente ao projecto de reparcelamento, pode a câmara municipal promover a aquisição dos respectivos terrenos pela via do direito privado ou, quando não seja possível, mediante o recurso à expropriação por utilidade pública." (sublinhado nosso).

É de facto nestas situações que faz todo o sentido - sob pena de se estar a beneficiar o proprietário que se recusa "a entrar" na concretização do projecto de reparcelamento previsto no plano -, não se contabilizar a mais-valia resultante do projecto expropriativo (consubstanciado no plano).

Diferente deve ser a solução quando é a Administração municipal que opta, sem mais, por excluir os proprietários do processo de reparcelamento (isto é, da concretização do plano de pormenor), ainda que estes tivessem vontade de aderir à operação, assumindo os seus encargos por forma a incorporar na sua esfera patrimonial as mais-valias decorrentes da operação.

Esta foi, aliás, a situação que ocorreu no caso subjacente ao aresto aqui em anotação. Com efeito, para a concretização dos objectivos que com o plano de pormenor em causa (Plano de Pormenor das Antas) se pretendiam alcançar ${ }^{16}$ previu-se, para os terrenos do expropriado, numa pequena parte, a ampliação dos espaços de circulação pedonal/passeios da Av. Fernão de Magalhães e da Alameda das Antas e na parte restante, a construção de edifícios de utilização mista (comércio habitação e serviços) com 6 pisos acima e 2 pisos abaixo do solo, de onde resultava ser opção do plano a substituição de uma moradia de habitação unifamiliar existente pela construção de edifícios destinados a habitação, comércio e equipamentos complementares, com admissão de indústria compatível.

O que se previa, porém, em termos de execução do plano, era a atribuição (distribuição) dos novos lotes resultantes da operação de reparcelamento concretizadora do plano de pormenor (coincidentes, em grande medida, com os anteriores, propriedade do expropriado) ao Futebol Clube do Porto e à Câmara Municipal, e não ao proprietário originário,

\footnotetext{
${ }^{16}$ Esses objectivos eram: “a) a criação de uma área central que articule, integre e valorize o território envolvente; b) a relocalização de grandes equipamentos desportivos; c) a redução dos impactes da via de cintura interna sobre a área de intervenção do Plano". Estes objectivos genéricos encontravam-se devidamente explicitados e concretizados no Relatório do plano, onde se afirmava serem eles: “a) a implantação do novo estádio tendo em consideração as valências urbanas deste novo tipo de equipamentos, a pressão que vai gerar sobre os acessos e estacionamento automóvel, o impacto visual do grande volume de construção e, sobretudo que a renovação que esta implantação origina permita "coser" as malhas urbanas envolventes através dos novos espaços públicos a criar e da nova estrutura viária; a localização na zona de dois outros equipamentos de grande capacidade de atracção, um pavilhão multiusos e uma superfície comercial de média dimensão, que contribuam para acentuar a sua centralidade; c) a estruturação de uma nova área urbana de usos mistos - residência, comércio e serviços - que será conseguida através da reconversão dos terrenos hoje ocupados pelas instalações do Futebol Clube do Porto e de outros terrenos e edifícios actualmente desocupados; d) o estabelecimento de uma estrutura de espaços públicos diversificados, centrada no novo estádio, que assegure as ligações urbanas com os bairros envolventes, nomeadamente Contumil, S. Roque da Lameira e Antas, rompendo com a barreira VCl; e) a estruturação de uma nova rede de espaços e corredores verdes que façam a ligação entre a estrutura verde existente e um conjunto de novas zonas e percursos verdes a criar; f) a melhoria das acessibilidades e da circulação na área de intervenção, em especial na relação da rede local com a rede primária da cidade, aproveitando a rede viária a criar na A.I. para melhorar a ligação entre as zonas do tecido urbano da cidade, que actualmente sofrem importantes descontinuidades".
} 
que, pura e simplesmente, foi excluído da operação. O que significa que esta exclusão não teve na sua base, ao contrário do que resulta do RJIGT, uma oposição ou desacordo do interessado em relação ao projecto de reparcelamento.

Para além de uma solução deste tipo apenas ser legítima se existirem razões fundamentadas de interesse público que a justifiquem, consideramos - precisamente porque a expropriação não surge como a superação de um obstáculo à concretização da operação de reparcelamento em que se consubstancia a execução do plano, mas na exclusão do proprietário da execução de um projecto urbanístico que cria valor à custa dos seus terrenos -, que terá de se permitir uma avaliação destes atendendo ao disposto no plano de pormenor em vigor à data da declaração da utilidade pública, sob pena de, por opção do plano, se estar a privar os proprietários da possibilidade de promoverem ou integrarem operações urbanísticas que valorizam os seus solos, incorporando na sua esfera patrimonial esse valor.

Neste caso, porém, e porque o plano de pormenor deverá estabelecer mecanismos de perequação (sendo que o reparcelamento também tem esse efeito), não deve o expropriado ser indemnizado atendendo à edificabilidade prevista no plano para as suas parcelas iniciais, mas pela edificabilidade média a que teria direito se entrasse na execução do plano, descontados os encargos que não assume (e teria de assumir caso entrasse na execução).

Com efeito, independentemente das concretas opções constantes do plano para cada parcela, os proprietários somente terão direito à edificabilidade média, apenas podendo utilizar a edificabilidade restante prevista no plano (nas situações em que a edificabilidade concreta for superior à média) se "pagar" por ela (designadamente por intermédio da cedência de terrenos). Donde não têm direito a esse excesso ou só o têm se pagarem por ele, o que significa que o mesmo não integra, à partida, a sua esfera patrimonial.

Prevendo o plano uma edificabilidade média, ela não pode ser ignorada quando as parcelas tenham de ser adquiridas por expropriação: embora esta exigência não resulte de forma expressa do Código das Expropriações (que apenas manda atender ao disposto nos instrumentos de planeamento em vigor), a mesma resulta de uma leitura necessariamente cruzada entre o disposto neste Código e no RJIGT que reconhece a perequação com um elemento indispensável e necessário em todos os escalões dos planos municipais; um elemento que não poderá deixar de ser tido em conta na execução destes instrumentos de planeamento territorial e, por isso, mesmo, nas expropriações que a visem implementar.

Por este motivo, mandando o Código das Expropriações atender aos planos municipais em vigor, e estabelecendo estes edificabilidades médias que correspondem aos direitos que são conferidos pelo plano, a aplicação dos referidos planos para a determinação do valor dos solos implicará necessariamente a consideração, nessa determinação, da edificabilidade média neles prevista. 